\title{
Agriculture ANd NATIONAL Welfare AROUND THE World: CAUSALITY AND INTERNATIONAL HETEROGENEITY SINCE 1960*
}

\author{
Claudio Bravo-Ortega \\ Office of the Chief Economist \\ Latin America and the Caribbean Region \\ The World Bank \\ and \\ Department of Economics \\ University of Chile
}

\author{
Daniel Lederman \\ Office of the Chief Economist \\ Latin America and the Caribbean Region \\ The World Bank
}

\section{All Comments are Welcome}

\begin{abstract}
Calculations of marginal welfare effects suggest that agricultural development has had important positive effects on national welfare, especially in developing countries. Latin American and Caribbean countries have also benefited from agricultural growth, but non-agricultural production has had marginal welfare effects that are greater in magnitude than those provided by agricultural activities. In contrast, the industrialized, high-income countries experienced marginal welfare gains from non-agricultural activities that are much greater than those derived from agriculture, whose impact is actually negative. These calculations of marginal welfare effects across regions depend on econometric estimates of elasticities linking agricultural and nonagricultural economic activities to four elements in a national welfare function: national GDP per capita, average income of the poorest households within countries, environmental outcomes concerning air and water pollution and deforestation, and macroeconomic volatility. The econometric analyses are motivated by theoretical treatments of key issues. The empirical models are estimated with various econometric techniques that deal with issues of causality and international heterogeneity.
\end{abstract}

World Bank Policy Research Working Paper 3499, February 2005

The Policy Research Working Paper Series disseminates the findings of work in progress to encourage the exchange of ideas about development issues. An objective of the series is to get the findings out quickly, even if the presentations are less than fully polished. The papers carry the names of the authors and should be cited accordingly. The findings, interpretations, and conclusions expressed in this paper are entirely those of the authors. They do not necessarily represent the view of the World Bank, its Executive Directors, or the countries they represent. Policy Research Working Papers are available online at http://econ.worldbank.org.

\footnotetext{
${ }^{*}$ Ramon López, William Maloney, Michael Walton, Guillermo Perry, Alberto Valdés, Julian Alston and William Foster provided valuable comments on preliminary drafts of this paper. We thank also participants at the World Bank conference in San Jose, Costa Rica. David Roodman kindly provided guidance on econometric estimators.
} 
"Had human institutions ... never disturbed the natural course ... the progressive wealth would, in every political society, be consequential, and in proportion to the improvement and cultivation of the territory...."

Adam Smith, The Wealth of Nations, Book Two.

\section{Introduction}

The literature on the role of agriculture in the process of economic development dates back to the work of the classic economists Adam Smith, David Ricardo, and Thomas Malthus. The modern literature includes numerous books and articles, including the influential works of Johnston and Mellor (1961) and Hayami and Ruttan (1970, 1985). There is an active current debate only partly inspired by the fact that in many developing countries agriculture still accounts for a significant share of gross domestic product (GDP). In fact, the dynamism of agricultural production and its insertion into the rest of the national economy has also been the subject of study in industrialized, high-income countries (e.g., Gardner 2002). Some of the main contributions to this debate and cross-country econometric exercises addressing related issues are summarized in Timmer (2002).

This paper contributes to this literature by exploring the relationship between agricultural production and national welfare defined broadly to include growth of the economy and its volatility, poverty or distributional effects, and environmental outcomes. The paper proposes a national welfare function that encompasses these four aspects of national welfare. We then theoretically and empirically address four key questions: What is the contribution of agriculture to national development? What is the contribution of agricultural development to the income of the poorest households within countries? What is the relationship between agriculture and environmental outcomes? And, how does agricultural output contribute to GDP volatility? In turn, estimated elasticities of the impact of agricultural and non-agricultural growth on the four 
elements of national welfare are used to calculate the contribution of agricultural development to national welfare. ${ }^{1}$

The calculations of marginal welfare effects obtained in this paper suggest that agricultural development has had important positive effects on national welfare, especially in developing countries. Latin American and Caribbean (LAC) countries have also benefited from agricultural growth, but non-agricultural production has had marginal welfare effects that are similar in magnitude to those provided by agricultural activities. In contrast, the industrialized, high-income countries experienced marginal welfare gains from non-agricultural activities that are much greater than those derived from agriculture.

These findings were derived from econometric analyses that rely on international data dating back to the 1960s in most analyses, depending on data availability. The required data come from publicly available sources from the World Bank (World Development Indicators), the Food and Agriculture Organization (FAO) of the United Nations and Dollar and Kraay's (2002) database. $^{2}$

The econometric analyses deal with key estimation challenges. First, we pay close attention to the issue of causality using econometric techniques that help identify the direction of causality between agricultural development and the performance of non-agricultural activities in the sense of Granger (1969). The Granger causality tests were estimated with panel-data techniques that rely on sequential instrumental variables in the context of general method of moments (GMM) estimators to identify the impact of agricultural growth on the variables of interest (Arellano 2003). When appropriate, we compare GMM IV estimations with results

\footnotetext{
${ }^{1}$ Johnston and Mellor (1961) list five contribution of agriculture to the process of development: increase the supply of food for domestic consumption, release labor for industrialized employment, enlarge the size of the market for industrial output, increase of domestic savings, and earn foreign exchange.

${ }^{2}$ See Appendix $\mathrm{C}$ for data definitions and data sources.
} 
derived from more traditional OLS and fixed-effects regressions. Second, we address the issue of international heterogeneity not only by controlling for international differences in the long-run average of levels or growth rates of agricultural GDP (i.e. we control for country-specific effects), but also by examining whether there is international heterogeneity in the elasticities linking agriculture and national welfare outcomes. Thus, for all these questions we also ask ourselves if one of the developing regions of the world, namely LAC, has behaved differently from other developing and developed countries.

The rest of the paper is organized as follows. The first section presents a framework for decomposing national welfare effects of agricultural (or non-agricultural) growth into its effects on the four dimensions of welfare. The main finding is that the marginal welfare effects of sectorial growth rates depend on a handful of observable or measurable parameters.

Section II examines the Chenery and Syrquin (1975) proposition that the share of agriculture in national GDP tends to decline with development. ${ }^{3}$ We find that the ChenerySyrquin relationship holds on average for the whole world, and for developing and developed countries separately. Moreover, it holds not only across countries, but also within countries. But agriculture's share in the average LAC country has tended to decline significantly more slowly than in other developing countries, which is due to this region's lower average share of agriculture in national GDP.

Section III examines the causal relationships between agricultural and non-agricultural GDP based on two alternative definitions of agriculture. One definition is limited to the production of agricultural commodities, whereas the second definition includes agricultural commodities plus the value of production of food and beverages. The evidence suggests that

\footnotetext{
${ }^{3}$ The declining share of agriculture during the process of development was documented by many studies prior to Chenery and Syrquin (1975). Johnston and Mellor (1961) list five references from the 1950s. The present authors use the term "Chenery-Syrquin relationship" for convenience.
} 
developing countries (but not high-income countries) in general have experienced positive effects from agriculture to the rest of the economy. LAC seems to have experienced even stronger positive effects than the other developing economies, and these effects were even larger when including the food processing industries as part of the agricultural sector.

Section IV studies the distributional effects of agricultural and non-agricultural labor productivity growth. In all developing countries, the average income of the poorest quintile of the income distribution is more favorably affected by growth in non-agricultural labor productivity than by agriculture.

Section V explores the impacts of various economic sectors on environmental outcomes. We focus on air pollution, fresh water withdrawals, and deforestation. The evidence shows that the size of the agricultural sector over time (within countries) does have significant effects on these environmental outcomes. However, we found significant international heterogeneity in the estimated effects of various sectors on the environment.

Section VI studies the impact of agriculture on GDP volatility. More specifically, we focus on the impact of agriculture on unexpected shocks to the rate of growth of the national GDP. We find that agriculture has higher volatility than non-agricultural output, and it contributes positively to unexpected shocks in developing countries to a greater extent than nonagricultural output.

Finally, section VII provides an estimate of the aggregate impact of agricultural development on national welfare for developing countries, LAC countries, and high-income countries, and contrasts them with those from the non-agricultural sector.

\section{Beyond GDP: Accounting for the Effect of Agriculture on National Welfare}


National welfare can be expressed as a utility function, which rises with GDP per capita (y), increases with the average income of the poorest quintile $(y 1)$, increases with an indicator of environmental quality $(E)$, and increases with the inverse of a measure of unexpected shocks or volatility ${ }^{4}$ :

$$
\text { Welfare }=\mathrm{U}(\mathrm{y}, \mathrm{y} 1, \mathrm{E}, 1 / \mathrm{v})
$$

For convenience, the functional form of the overall welfare function can be thought to be of the Cobb-Douglas form, so that $U=y^{\alpha}(y 1)^{\beta} E^{(\gamma)}\left(\frac{1}{v}\right)^{(1-\alpha-\beta-\gamma)}$. We can think in this function as the utility function that a policy maker might have in his mind when taking policy decisions, or the aggregation of individual preferences. ${ }^{5}$ The $\alpha, \beta, \gamma$ parameters are unknown weights of each element in the overall national welfare function. In the final section of this paper we use alternative weights to compare the marginal welfare effects of agriculture (A) and nonagricultural production $(\mathrm{N})$ across regions. The elasticity of national welfare with respect to A is given by the sum of the marginal effects of $\mathrm{A}$ on $\mathrm{U}$ through each element of the welfare function:

$$
\frac{d U}{d A} \frac{A}{U}=\alpha \frac{\partial y}{\partial A} \frac{A}{y}+\beta \frac{\partial y 1}{\partial A} \frac{A}{y 1}+\gamma \frac{\partial E}{\partial A} \frac{A}{E}-(1-\alpha-\beta-\gamma) \frac{\partial v}{\partial A} \frac{A}{v} .
$$

To calculate the welfare elasticity with respect to A, we need to examine its marginal contribution to each of the four elements in (2). ${ }^{6}$ First, $y$ is the ratio of output over population $\mathrm{Q} / \mathrm{G}$. In turn, $\mathrm{Q}$ is composed of agricultural (A) and non-agricultural output $(\mathrm{N}), \mathrm{Q}=\mathrm{A}+\mathrm{N}$. Since

\footnotetext{
${ }^{4}$ Volatility is defined later.

${ }^{5}$ Houthakker (1955) shows that a Cobb-Douglas production function corresponds to the aggregation of Leontieff production function at a firm level, in which technological parameters follow a multivariated Pareto distribution. We therefore can think in this Cobb-Douglas social welfare function as a particular aggregation of Leontieff policy preferences of the population.

${ }^{6}$ For each component of the utility function we assume that there are a direct effect of agriculture and also and indirect effect of agriculture through the non-agricultural sector. Mathematically if $\mathrm{N}$ is the non-agricultural sector we assume $\mathrm{N}=\mathrm{N}(\mathrm{A}, \mathrm{X})$, with $\mathrm{A}$ equals to the agricultural sector and $\mathrm{X}$ other determinants.
} 
$\mathrm{y}=\frac{\mathrm{Q}}{G}=\frac{\mathrm{A}+\mathrm{N}}{\mathrm{G}_{\mathrm{u}}+\mathrm{G}_{\mathrm{r}}}$, then $\frac{\partial y}{\partial A}=\left(\left(1+\frac{\partial N}{\partial A}\right)-\frac{\partial G}{\partial A} y\right) \frac{1}{G}$, where $\frac{\partial N}{\partial A}$ represents externalities plus multiplier effects of agriculture on non-agricultural GDP. ${ }^{7}$ By letting population changes be exogenous to agricultural output, the marginal effect of A on $y$ boils down to the its impact on $\mathrm{N}$ : $\frac{\partial y}{\partial A}=\left(1+\frac{\partial N}{\partial A}\right) \frac{1}{G}$.

Regarding the second element in (2), the average income of the poor $y 1$ is a weighted average of rural and urban incomes of the poor, both of which are functions of agricultural income and other determinants. Consider that the bottom quintile is defined as $y 1=\frac{Q_{1}}{G_{1}}$, with $Q_{1}$ the total income and $G_{1}$ the population of the bottom quintile. In section III below we provide econometric estimates of: $e_{y_{1},\left(A / L_{A}\right)}=\frac{d y 1}{d\left(A / L_{A}\right)} \frac{A / L_{A}}{y 1}$ and $e_{y_{1},\left(N / L_{N}\right)}=\frac{d y 1}{d\left(N / L_{N}\right)} \frac{N / L_{N}}{y 1}$. These are elasticities of income per capita of the bottom quintile with respect to output per worker in A and $\mathrm{N}$ respectively. The income of the poorest quintile of the population is also a function of the labor and the value of production in $\mathrm{A}$ and $\mathrm{N}$ : $y 1=f\left(A, N, L_{A}, L_{N}\right)$. Thus $e_{y_{1},(A / L)}=\frac{\partial y 1}{\partial(A / L)} \frac{(A / L)}{y 1}=\frac{\partial y_{1}}{\partial A} \frac{L}{L} \frac{A}{y 1}=e_{y_{1}, A}$, and there is an analogous result for $e_{y_{1},(N / L)}$. The derivative of $y l$ with respect to $\mathrm{A} / \mathrm{L}_{\mathrm{A}}$ can therefore be expressed as a function of the marginal effect of A on $y 1$ plus an indirect effect via A's impact on $\mathrm{N}$ :

$\frac{d y_{1}}{d\left(A / L_{A}\right)}=f\left(A, N, L_{A}\right)=\frac{\partial y_{1}}{\partial A} L_{A}+\frac{\partial y_{1}}{\partial N} \frac{\partial N}{\partial A} L_{A}=e_{y_{1},\left(A / L_{A}\right)} \frac{y_{1}}{A / L_{A}}+e_{y_{1},\left(N / L_{N}\right)} \cdot e_{N, A} \cdot \frac{y_{1}}{A / L_{A}}$, where $e_{x, y}$ 's are cross elasticities.

\footnotetext{
${ }^{7}$ Section III.A. below provides an economic model of the interactions between A and N. Section III.C. discusses econometric estimates of the net effect of a resource-pull effect plus externalities.
} 
Regarding the third element in welfare function (2), environmental quality is defined as a land-weighted average of rural and urban environmental qualities, although alternative weights can be used. Define an index of environmental quality as follows:

$E=E_{1}{ }^{\gamma_{1}} E_{2}{ }^{\gamma_{2}} E_{3}{ }^{1-\gamma_{1}-\gamma_{2}}$, where $E_{1}, E_{2}, E_{3}$ represent three environmental outcomes. In particular $E_{1}$ and $E_{2}$ are measured with respect to a reference level of pollution per capita. That is, $E_{1}$, $E_{2}, E_{3}$ are defined as

$E_{1}=\left(M_{1}-\frac{E_{1}^{\prime}}{G}\right), E_{2}=\left(M_{2}-\frac{E_{2}^{\prime}}{G}\right), E_{3}=\left(\frac{1}{E_{3}^{\prime}}\right)$. This is necessary so that $E_{1}, E_{2}$ and $E_{3}$ are indicators of environmental quality. $M_{1}$ and $M_{2}$ are maximum reference points of pollution in per capita terms so that $E_{1}, E_{2}$ measure environmental quality with respect to an observed maximum. The resulting marginal effect of $A$ on $E$ is $\frac{\partial E}{\partial A}=\gamma_{1} \cdot \frac{E}{E_{1}} \frac{\partial E_{1}}{\partial A}+\gamma_{2} \cdot \frac{E}{E_{2}} \frac{\partial E_{2}}{\partial A}+\left(1-\gamma_{1}-\gamma_{2}\right) \cdot \frac{E}{E_{3}} \frac{\partial E_{3}}{\partial A}+$ $+\left(\gamma_{1} \cdot \frac{E}{E_{1}} \frac{\partial E_{1}}{\partial N}+\gamma_{2} \cdot \frac{E}{E_{2}} \frac{\partial E_{2}}{\partial N}+\left(1-\gamma_{1}-\gamma_{2}\right) \cdot \frac{E}{E_{3}} \frac{\partial E_{3}}{\partial N}\right) \frac{\partial N}{\partial A}$, where the $\gamma$ 's are unknown parameters that determine the weight of each component in the environmental index. Our calculations discussed at the end of this paper assume that these weights are equal.

The impact of agriculture on GDP volatility can be expressed as follows:

$\frac{\partial \frac{1}{v}}{\partial A}=-\frac{1}{v^{2}}\left(\frac{\partial v}{\partial A}+\frac{\partial v}{\partial N} \frac{\partial N}{\partial A}\right)$. Thus we can finally derive the elasticity of national welfare with respect to agriculture by inserting the expanded expressions for marginal effects of A on $y, y l, E$ and $1 / v$, into equation (2) above: 


$$
\begin{aligned}
& \frac{d U}{d A} \frac{A}{U}=\alpha\left(S_{A}+e_{N, A} \cdot S_{N}\right)+\beta \cdot\left(e_{y_{1},(A / L)}+e_{y_{1},(N / L)} \cdot e_{N, A}\right)+ \\
& +\gamma\left[\begin{array}{l}
\gamma_{1}\left(\frac{E_{1}^{\prime}}{G \cdot E_{1}}\left(-e_{E^{\prime}, A}\right)\right)+\gamma_{2}\left(\frac{E_{2}^{\prime}}{G \cdot E_{2}}\left(-e_{E^{\prime}, A}\right)\right)+e_{N, A}\left[\gamma_{1}\left(\frac{E_{1}^{\prime}}{G \cdot E_{1}}\left(-e_{E^{\prime}, N}\right)\right)+\gamma_{2}\left(\frac{E_{2}^{\prime}}{G \cdot E_{2}}\left(-e_{E_{2}^{\prime}, N}\right)\right)\right]+ \\
-\left(1-\gamma_{1}-\gamma_{2}\right)\left(e_{E_{3}^{\prime}, A}+e_{E_{3}^{\prime}, N} e_{N, A}\right)
\end{array}\right]+ \\
& -(1-\alpha-\beta-\gamma)\left(e_{v, A}+e_{v, N} \cdot e_{N, A}\right)
\end{aligned}
$$

where $S_{A}$ and $S_{N}$ are the sectorial GDP shares. This decomposition allows us to recover the marginal contribution of both sectors to national welfare. In section III below we estimate the value of $e_{N, A}$, i.e., the elasticity of $\mathrm{N}$ with respect to $\mathrm{A}$. In section IV we estimate $e_{y_{1},(A / L)}, e_{y_{1},(N / L)}$, i.e., the elasticities of $y l$ with respect to $\mathrm{A} / \mathrm{L}$ and $\mathrm{N} / \mathrm{L}$. In section $\mathrm{V}$ we estimate

$e_{E_{1}^{\prime}, A}, e_{E_{2}^{\prime}, A}, e_{E_{3}^{\prime}, A}, e_{E_{1}^{\prime}, N}, e_{E_{2}^{\prime}, N}, e_{E_{3}^{\prime}, N}$, the elasticities of three measures of environmental with respect to A and N. Finally, in section VI we estimate the elasticities of unexpected macroeconomic shocks with respect to $\mathrm{A}$ and $\mathrm{N}$, i.e., $e_{x, y}$.

This section has thus provided a theoretical framework for accounting for the contribution of agricultural growth on a broad measure of national welfare that considers its effects on national development, the income of the poorest quintile of the population, the environment and GDP volatility. The following section turns to questions related to theoretical and empirical linkages between agriculture and the rest of the economy.

\section{The Chenery-Syrquin Relationship: Understanding the Trends}

Chenery and Syrquin (1975) find that the share of agriculture in GDP decreases with the process of development. This relationship can be expressed as : 


$$
a s=\beta \cdot \ln \left(y_{p c}\right){ }^{8}
$$

where as corresponds to the agricultural share in GDP, and $e_{\dot{E}_{1}, A}$ is income per capita. The Chenery-Syrquin relationship holds when $\beta$ is negative. Let $a s=\frac{A}{Y}$, where A is the agricultural output and Y is total GDP. Also, define per capita income as $y_{p c}=\frac{Y}{P O P}$, where POP is national population. Totally differentiating expression (4) yields:

$$
\beta=\frac{d(a s) y_{p c}}{d\left(y_{p c}\right)}
$$

After some algebra, $\beta$ can be expressed as:

$$
\beta=\left(\frac{d A}{A}-\frac{d Y}{Y}\right) \frac{1}{\left(\frac{d Y}{Y}-\frac{d P O P}{P O P}\right)} \cdot \frac{A}{Y}
$$

Equation (6) implies that the rate of growth of the agricultural sector needs to be lower than GDP growth in order for beta to be negative. Furthermore, positive long-run growth rates of GDP per capita imply that the expression within parentheses in the denominator on the right-hand side of (6) is positive. Since these assumptions hold for our sample (see Appendix A), $\beta$ tends to be greater in absolute terms in countries with a larger share of agricultural GDP. This implies that we should in fact observe great international heterogeneity in the magnitude of $\beta$, since national growth rates and the share of agriculture do tend to vary greatly across countries and regions. For example, since LAC countries on average tended to have lower GDP shares of agriculture than other poor countries, the former should have lower absolute values of $\beta$.

\footnotetext{
${ }^{8}$ We use this semi-log specification because by totally differentiating this expression we obtain percentage point changes on both sides.
} 
To study the empirical Chenery-Syrquin relationship, we use agricultural GDP and income per capita expressed in 1995 US\$ obtained from the World Development Indicators 2003 of the World Bank. ${ }^{9}$ The data cover the period 1960-2002. Figures 1 is a scatter plot of agriculture's GDP share as a function of income per capita. Fitted regression lines are drawn for the whole sample and for LAC. The two sub-samples do not seem to have different $\beta$ 's . However, this graph is inappropriate for examining international heterogeneity in the $\beta$ 's because it does not control for long-run heterogeneity in agricultural GDP shares and GDP per capita.

Table 1 presents econometric estimates of $\beta$ across several specifications and estimations methods. All estimations use annual data. The first column presents the estimate of $\beta$ derived from the pooled data. Columns (2)-(4) present estimates from country fixed-effects regressions, whereas columns (5)-(10) present results from two-stage regressions with fixed effects (Baltagi 2002). Consequently all the estimates of $\beta$ under columns (2)-(10) correspond to the effect of development (increases in the log GDP per capita) on agriculture's GDP share over time, within countries. The instrumental variables for the IV regressions are the 5-15 years lagged observations of log GDP per capita. The p-value of the Sargan test for the validity of the instruments are listed toward the bottom of Table 1. The null hypothesis of the Sargan test is that the instruments are not correlated with the errors, and thus a p-value above 0.05 indicates that the we cannot reject the null and thus the instruments are valid. This is the case for regressions (6) (10). In all of them we observe a negative and significant $\beta$.

Models (3)-(4) and (6)-(8) also include a time trend, which is also statistically significant. Moreover, regression (8) includes dummy variables identifying high-income and LAC countries

\footnotetext{
${ }^{9}$ See Appendix C for data definitions and primary sources.
} 
multiplied times the log GDP per capita. This implies that the reference group is composed of non-LAC poor countries. The LAC $\beta$ is thus the sum of the coefficient on the log of GDP per capita variable plus the coefficient of the log GDP per capita multiplied by the LAC dummy variable. As predicted by theory, the results show a stronger negative relationship for the reference group, a weaker negative relationship for LAC, and an insignificant coefficient in highincome countries.

Nevertheless, the fact that the Chenery-Syrquin relationship holds throughout the developing world says very little about the economic forces behind the decline of agriculture. The "traditional" explanations were summarized by Johnston and Mellor (1961) in three factors that might explain why agriculture's share in national GDP tends to decline with development: (a) income elasticities of demand less than unity for agriculture; (b) agricultural expansion with a constant or declining farm labor force; and (c) technological progress that favors manufacturing. Johnston and Mellor argued that agriculture could actually contribute to national development through channels that contradict the traditional economic transformation model. These authors provided five reasons why agriculture can actually have a positive impact on non-agricultural development: (d) demand for agricultural products rises with development and lack of supply can obstruct growth; (e) agricultural exports can help reduce foreign exchange constraints; (f) the manufacturing labor force has to be drawn from agricultural production with rising labor (and land) productivity; (g) agriculture can contribute to national savings and provide capital for investment; and (h) rising incomes of the rural population dedicated to farming can expand demand for manufactures. All these arguments are now outdated for a world economy where imports can satisfy domestic demand for food and agricultural products. Furthermore, technological progress in agriculture seems to have been more rapid, at least in terms of 
measured total factor productivity growth, than in manufacturing in both developed and developing countries (Martin and Mitra 2001; Bernard and Jones 1996).

In sum, understanding how agricultural development affects the growth of the rest of the economy seems to demand further analysis of two opposing forces. On the one hand, the growth of agriculture requires the employment of factors of production, and thus there might be a resource-pull effect whereby agriculture grows at the expense of the rest of the productive economy. On the other hand, productivity gains in agriculture might have positive externalities and multiplier effects on the rest of the economy. These positive effects could be related to the technological improvements themselves (i.e., a new machine for harvesting crops might instigate inventions with applications in manufacturing industries or might increase demand for the production of these machines) or could be related to indirect effects. The latter includes the release of labor and capital from agriculture -- a reverse resource-pull effect - combined with increased demand for non-agricultural products. The general point, however, is that the declining share of agriculture in national production could be due to the virtues of agriculture, rather than to weaknesses. The following section explores the channels of influence of agriculture on the rest of the economy in a more formal economic model, which is then followed by an empirical investigation.

\section{The Contribution of Agriculture to Non-Agricultural Development}

Consider an economy with two economic sectors -- industry (I) and agriculture (A). The resource-pull effects can be captured in a model with one common factor of production across sectors -- human capital. Assume that there is one specific factor to each sector. In agriculture land $(\mathrm{T})$ is its fixed factor, whereas industry uses a certain type of capital (K). Finally assume 
that agriculture has a productivity coefficient A, and industry has a productivity coefficient I. Further assume that industry exhibits constant returns to human capital whereas agriculture experiences decreasing marginal returns to human capital. ${ }^{10}$ These last assumptions are consistent with the evidence showing that agricultural production has the same elasticities for education as for labor (Griliches 1963a, 1964). The resulting aggregate production function can be expressed as follows:

$$
Y_{T}=Y_{A}+Y_{I}=A \cdot T \cdot H_{A}^{\alpha}+I \cdot K \cdot H_{I}
$$

Equilibrium in the labor market implies that the return to human capital equals IK and that human capital allocated to agriculture and industry will be given by:

$$
\begin{aligned}
& H_{A}=\left(\frac{\alpha \cdot A \cdot T}{I \cdot K}\right)^{\frac{1}{1-\alpha}}, \text { and } \\
& H_{I}=H_{T}-H_{A}=H_{T}-\left(\frac{\alpha T}{K}\right)^{\frac{1}{1-\alpha}}
\end{aligned}
$$

where $\mathrm{H}_{\mathrm{T}}$ is the total level of human capital in the economy.

This simple framework contains some relevant properties. First, the level of human capital allocated to agriculture will increase as a consequence of either an increase in land devoted to agriculture or by an increase in its productivity coefficient. As expected an increase in the level of capital in the industrial sector or in its productivity will decrease the human capital devoted to agriculture. Assuming that we can express the level of human capital in either sector as $H_{j}=h L_{j}$ with $h$ being the level of human capital per capita and $L_{j}$ the share of the population in sector $\mathrm{j}$, then the share of the population that works in agriculture will decline with either an

\footnotetext{
${ }^{10}$ This assumption seems reasonable to us given the fixed endowments of land existing in the agricultural production.
} 
increase in the level of capital in the industrial sector or with an increase in the average level of human capital. Formally,

$$
L_{A}=\frac{1}{h}\left(\frac{\alpha \cdot A \cdot T}{I \cdot K}\right)^{\frac{1}{1-\alpha}} .
$$

To consider the potential role of productivity externalities, assume that the productivity of the industrial sector is a function of the level of human capital and the productivity in agriculture. Likewise, agricultural productivity is a function of the productivity of the industrial sector and other factors.

Given that human capital and the size of the labor force are fixed in this model, the growth of any sector will have to come from gains in productivity. Therefore, we can analyze the impact that the growth in the agricultural sector will have on the industrial sector by differentiating the industry production function with respect to the productivity of the agricultural sector, and vice versa. That is, the output of the industrial sector can be expressed as:

(10a) $\frac{d Y_{I}}{d A}=\frac{\partial Y_{I}}{\partial I} \frac{\partial I}{\partial A}+\frac{\partial Y_{I}}{\partial H_{I}} \frac{\partial H_{I}}{\partial A}=K H_{I} \frac{\partial I}{\partial A}+I K\left(-\frac{\partial H_{A}}{\partial A}\right)$

The first term on the right side is positive whereas the second term is negative. Therefore the impact of agricultural development on industrial growth is theoretically ambiguous. The first term corresponds to the externalities from agriculture (or to a multiplier effect) to the industrial sector, while the second comes from the human capital "pull effect" that brings workers to the agricultural sector. Similarly for the agricultural sector we have:

$$
\frac{d Y_{A}}{d I}=\frac{\partial Y_{A}}{\partial A} \frac{\partial A}{\partial I}+\frac{\partial Y_{A}}{\partial H_{A}} \frac{\partial H_{A}}{\partial I}=T \cdot H_{A}{ }^{\alpha} \frac{\partial A}{\partial I}+\alpha \cdot A \cdot T \cdot H_{A}{ }^{\alpha-1}\left(\frac{\partial H_{A}}{\partial I}\right)
$$

In short, an increase in the productivity of one sector will imply a labor-pull effect on the other sector. However, the existence of externalities will imply a positive feedback from the 
productivity of one sector to the other. Therefore, whether the resource-pull effect predominates over the productivity spillovers is an empirical question. This model also highlights the fact that the Chenery-Syrquin relationship could be due to the predominance of positive externalities whereby agricultural growth lead to non-agricultural growth combined with lower externalities going from the industrial sector to agriculture. We could call this the "dynamic agriculture" scenario. In contrast, the declining share of agriculture could also be explained by the reverse scenario and/or by a resource-pull effect whereby industrial growth attracts human capital away from agriculture. Thus, our theoretical and empirical approaches take distance of "results" that were considered for long time crucial in shaping the process of economic policies for development. Prebisch (1950) affirmed that agriculture and activities related to natural-resource extraction would contribute to the stagnation of the economy given "declining terms of trade." Hirschman (1958) argued that agriculture presents lower linkages to the rest of the economy, therefore implying the superiority of manufacturing in playing the role of engine of the development of the economy.

Finally, is noteworthy to discuss some interesting features of the presented model and that are consistent with the evolution of the agricultural sector in developing countries. By looking at equation (8a) and (9) we can note that and increase in agricultural productivity always will increase the total amount of human capital devoted to agriculture and therefore will create a resource pull effect, however if there is a significant increase in the endowment of human capital there it is possible that an important fraction of the labor force exits agriculture. ${ }^{11}$ This phenomenon is described by Aquaye, Alston and Pardey (2003) for the evolution of agriculture in the U.S. of the post-war. It is also important to note that an important TFP growth in agriculture does not say anything about the cross effects of agriculture on the non-agricultural

\footnotetext{
${ }^{11}$ For a complementary view on the intersectoral migration of agricultural labor see Larson and Mundlak (1997)
} 
sector, therefore is an empirical question whether a TFP increase in agriculture entails positive or negative effects on the rest of the economy. Is our understanding that this paper is the first one that tries to answer the previous question.

The following pages describe the empirical analysis used to explore the relationship between agricultural development and the performance of the rest of the economy.

\section{III.A. Data}

The data on agricultural and non-agricultural GDP, total labor force, total population were obtained from the World Development Indicators 2003 from the World Bank. We use two measures of agricultural output. The first measure corresponds to the agricultural sector's output, while our second measure adds to the first the output in the food, beverages, and tobacco sector. The size of the rural labor force, reported every ten years, was obtained from FAOSTAT. ${ }^{12}$ The data gaps were filled by assuming an exponential growth rate of the rural labor force. Appendix A contains the resulting rural labor force shares (divided by the national labor force).

\section{B. Empirical analysis I: Revisiting Timmer (2002)}

As a first step we try to replicate the results reported by Timmer (2002) who report positive correlations between agricultural growth and growth of national GDP per capita. For that purpose we constructed a panel data set with five-year averages, covering 1960-2000. We computed the rates of growth of non-agricultural and agricultural output. For agricultural output we consider both of the aforementioned agricultural sectors. We estimated pooled and fixedeffects regressions. The results are reported in Tables 2 (a) through 2 (d). Tables 2 (a) and 2 (b) study the relationship between agricultural and non-agricultural growth using non-agricultural

\footnotetext{
${ }^{12}$ See Appendix C for data definitions and primary sources.
} 
growth as the dependent variable. For both measures agricultural output we find a positive and significant correlation for both pooled and fixed-effects estimations. These results are consistent with those reported by Timmer (2002).

Tables 2 (c) and 2 (d) study the reverse relationship, where the dependent variable is agricultural growth and the explanatory variables are the contemporaneous and lagged nonagricultural growth rates. This relationship is not explored in Timmer (2002), but it is relevant because the results reported in Tables 2 (a) and 2(b) can be misinterpreted as supporting policies that favor agriculture. The results in Tables 2 (c) and 2 (d) show that there is also a net positive relationship between non-agricultural and agricultural growth for both measures of agriculture and for both pooled and fixed-effects estimations. Thus Timmer's approach is hardly conclusive, mainly due to the endogeneity problems afflicting his estimations. In the next section we propose a new approach in order to explore the causal relationship between agricultural and nonagricultural output.

\section{III.C. Empirical analysis II: Causal effects across sectors}

We employ a parametric test to determine whether there exists evidence of a causal relationship between agricultural and non-agricultural output. We follow the concept of causality proposed by Granger (1969), according to which variable $X$ "Granger-causes" a variable $Y$ if $Y$ can be better predicted when past values of $X$ are used for forecasting than without them. The specification we use in our Granger-causality tests given variables $X$ and $Y$, is the following:

(11a) $Y_{i, t}=\alpha_{0}+\alpha_{1} Y_{i, t-1}+\alpha_{2} X_{i, t-1}+\eta_{i}+\gamma_{t}+\varepsilon_{i, t}$, and

(11b) $X_{i, t}=\beta_{0}+\beta_{1} X_{i, t-1}+\beta_{2} Y i_{t-1}+\eta_{i}+\gamma_{t}+\varepsilon_{i, t}$. 
Subscript $i$ represents countries and subscript $t$ identifies periods of time. The $\eta_{i}$ 's are unobserved, time-invariant country characteristics, and $\gamma_{t}$ are period-specific shocks that are common to all countries. We estimate equations (11a) and (11b) in first differences and levels by using a system estimator. The period effects are captured by period-specific dummy variables, which are treated as strictly exogenous. To ensure consistent estimates of the alphas and beta coefficients in (11a) and (11b), we follow Arellano and Bover (1995) by estimating the models via GMM using as instrumental variables lagged levels for the equation in differences and lagged differences for the equation in levels. In our case, the Y's and X's are the logarithms of agricultural and non-agricultural GDP, and thus our estimations do not suffer from the weakinstrument problem that afflicts the Arellano-Bond estimation when the data-generation process of the variables of interest approaches a unit root (see Arellano 2003 and references therein). We conclude that $X t(Y t)$ Granger-causes $Y t(X t)$ if $\alpha_{2}\left(\beta_{2}\right)$ in equation (11a) ((11b)) is statistically different from zero. If $\alpha_{2}$ and $\beta_{2}$ are both statistically significant then there is feedback between $X t$ and Yt. If Granger causality is found only in one direction, the explanatory variable is said to Granger-cause the dependent variable.

To study the cross regional heterogeneity in the alphas and betas, we also estimate extensions to the models represented by equations (11a) and (11b). For example, to test whether LAC's causal effects are different from the rest of the sample, one can estimate models (11c) and 11(d):

$$
\begin{aligned}
& Y_{i, t}=\alpha_{0}+\alpha_{1} Y_{i, t-1}+\alpha_{1, L A C} L A C \bullet Y_{i, t-1}+\alpha_{2} X_{i, t-1}+\alpha_{2, L A C} L A C \bullet X_{i, t-a}+\eta_{i}+\gamma_{t}+\varepsilon_{i, t} \\
& X_{i, t}=\beta_{0}+\beta_{1} X_{i, t-1}+\beta_{1, L A C} L A C \bullet X_{i, t-1}+\beta_{2} Y i_{t,-1}+\beta_{2, L A C} L A C \bullet Y_{i, t-1}+\eta_{i}+\gamma_{t}+\varepsilon_{i, t} .
\end{aligned}
$$

In this specification, the effect of X on Y for LAC would be equal to the sum of $\alpha_{2}$ plus $\alpha_{2, L A C}$. 
Table 3 reports results for the Granger causality tests. Table 3 (a) presents pooled, fixedeffects (FE), and GMM system estimations for the relationship between agricultural output in time (t-1) and non-agricultural output in time (t), assuming homogeneous coefficients across regions. The estimates reflect the expected direction of the bias of the endogenous variable in the pooled and FE regressions with respect to the GMM estimates. That is, the pooled-data estimator of the lagged dependent variable (non agricultural growth in period t-1) is significantly higher than the one predicted by the FE estimator, as predicted by econometric theory. The estimated coefficient of the lagged dependent variable derived from the Arellano-Bover GMM system estimator falls between the pooled OLS and the FE estimates, but Hansen's test suggests that the instruments might not be valid. This could be due to the presence of heterogeneity in the coefficients. In any case, the results in Table 3 (a) suggest that agricultural development does cause non-agricultural growth for the world data.

Table 3 (b) presents results from regressions that deal with group heterogeneity by interacting the lagged explanatory variables with LAC and high-income dummy variables. Thus the reference group is composed of non-LAC developing countries. The bottom rows of the table report the LAC and high-income coefficients together with the probability values of the corresponding F-tests. The first two columns report coefficients for the full sample (128 countries) whereas the results under columns (3)-(6) use a sample of 80 countries that have data for both definitions of agriculture.

The results in the first column suggest a significant causal effect going from agricultural to non-agricultural output. However, this effect is slightly smaller in LAC countries than in the reference group, and it is negative for developed countries. These results do not change significantly with the reduced sample. For the large sample, agricultural output is caused by non- 
agricultural output in poor countries. Non-LAC developing countries exhibit a predominant resource-pull effect reflected in a negative and statistically significant coefficient on the lagged non-agricultural output variable. The results under column 3 suggest that for all developing countries agricultural output has a positive effect on non-agriculture, whereas this is not true for high-income countries. In contrast, the results under column 4 indicate that for developing countries there is an effect going from non-agriculture to agricultural growth for poor non-LAC and high-income countries, whereas this effect is not significant for LAC countries. ${ }^{13}$

When the agricultural sector includes the food industries, the results are a bit different. The estimates under column 5 of Table 3(b) show that the net positive effects from agriculture to non-agricultural output are larger in LAC countries when including the food industries than for commodity agriculture. This last fact can be explained by noting that in LAC the share of agriculture in GDP shows a very significant increase once the food processing industry is added (See Appendix A). Finally, model 6 suggests that the expanded definition of agricultural output is not affected by past non-agricultural output in all countries.

In sum, we found evidence that agriculture might have net positive causal effects on nonagricultural growth in developing countries. These positive effects in LAC are also higher when agriculture includes the downstream industries associated with food processing. The evidence concerning the cross-sector effects are considered in the calculations of welfare elasticities discussed in the conclusions, for they reflect each sector's contribution to national GDP per capita as well as their indirect effects on the other elements of the welfare function.

\section{The Impact of Agricultural Productivity on Quintile Incomes}

\footnotetext{
${ }^{13}$ This analysis and the following paragraph are based on the p-values of the F-tests reported at the bottom of table 3(b).
} 
There is little doubt that economic growth reduces poverty (e.g., Dollar and Kraay 2002). However, sectorial growth rates might have a different impact on the poor. Ravallion and Datt (1996) do not find any impact of Indian manufacturing growth on the poor, even in urban areas, whereas rural growth reduced poverty both in rural and urban areas. Gallup, Radelet, and Warner (1997) find that a one percent growth in agricultural GDP per capita leads to a 1.61 percent increase in per capita income of the bottom quintile, whereas an equivalent increase in industrial GDP increases the income of the bottom quintile by only 1.16 percent. ${ }^{14}$ Unfortunately the data used by these authors only included 35 developing countries and the differences in the sector effects were not statistically significant. Timmer (2002) studies the contribution of agricultural and non-agricultural output per worker to the income per capita across quintiles of the income distribution. Although he finds a slightly greater impact of agricultural output, it is unlikely that the sector differences in his estimations were statistically significant.

The data on income shares across quintiles come from Dollar and Kraay (2002) and the per capita incomes from the World Bank's World Development Indicators 2003. ${ }^{15}$ The resulting data span from 1960 to 2000. The econometric estimations utilize a panel of five-year averages. To study the contribution of agricultural GDP to the income of different quintiles, we estimate our specifications using GMM in order to deal with the endogeneity of the sector GDPs. This is the main difference between our work and what has been done so far in the literature. More specifically, the GMM IV system estimations, which were explained in Section III.C., use appropriate lags of the sectorial GDPs as instrumental variables.

Table 4 reports the impact of output per worker in agriculture and non- agriculture on the income per capita of each quintile while also controlling for regional heterogeneity. The results

\footnotetext{
${ }^{14}$ This paper was cited by Timmer (2002). We thank him for providing us a copy of it.

${ }^{15}$ See Appendix C for data definitions and primary sources.
} 
imply that agricultural labor productivity has a significant effect on the average income of the first quintile and does not show significant heterogeneity across regions. But agricultural output per worker has a smaller effect than non-agricultural output per worker on the average income of the first quintile. The estimate of the impact of non-agricultural output per worker on the income of the first quintile does not show heterogeneity across regions.

There are some surprising results regarding the income of quintiles 2 through 5. First, agricultural output per worker explains an increasing share of the income of quintiles 2 and 3 for the group of poor and LAC countries. However, non-agricultural output per worker explains most of the income for all quintiles and all groups of countries. This impact is significantly larger for LAC quintiles 2, 4 and 5 than for other poor countries. This effect is even larger for highincome countries for quintiles 2-5.

\section{Environmental Outcomes}

This section explores the determinants of three environmental outcomes: Co2 emissions, fresh water withdrawals, and deforestation. The analyses explain the evolution of these variables by the output of five economic sectors that account for total GDP: agriculture; food, beverages, and tobacco; manufacturing; services; and other industries. The food industries are included in manufactures, and therefore their coefficient must be interpreted with caution. It provides an estimate of the marginal effect of the food processing industries on environmental outcomes above and beyond the average marginal effect of the whole manufacturing sector.

The study of cross country comparisons on the determinants of environmental quality starts with Grossman and Krueger (1995) and Shafik (1994) who claim the existence of a environmental Kuznets curve, whereby pollution would increase with development reaching a 
maximum at a certain level of income and decreasing from then on. The existence of this relationship as pointed by Cole (2003) has been criticized on grounds of the endogeneity problems afflicting some estimations, the unexplored impact of trade openness, the restriction of some samples to OECD countries, non stationarity of some series and heteroscedasticity on cross-section data. Cole (2003) takes into accounts these considerations and he still finds the existence of U-inverted Kuznets curve for some pollutants. However, Cole's approach has been strongly criticized by Stern (2004) subtracting validity to his conclusions. Moreover, there is important evidence mostly based on time series that rejects the existence of the Kuznets curve. ${ }^{16}$ In our approach we are sympathetic of Stern (2004) and Copeland and Taylor (2004) skepticism about the existence an environmental Kuznets curve, however if there is Kuznets curve its effect should be captured by the regional interacted dummies we use, given that this dummies are highly correlated with levels of income. ${ }^{17}$ Beside these interacted terms our analyses encompasses the study of the impact of the productive structure on the environmental outcomes, in particular those of agricultural and non agricultural sectors.

The data on sectorial output, $\mathrm{C} 02$ emissions, and water withdrawals were obtained from the World Development Indicators 2004. The forests areas were obtained from FAO. The data on air pollution covers the $1970-2000$ period, the fresh water data is from the year 2000 , and the forest coverage data is from two years, namely 1990 and $2000 .^{18}$

Table 5 (a) reports results from country fixed-effects (FE) estimations of sectorial determinants of $\mathrm{CO} 2$ emissions, thus assuming that sectorial outputs are exogenous to air pollution. The probability values of the F-test of the significance of the coefficients associated with LAC for the five economic sectors are reported at the bottom of the table. Regression (1)

\footnotetext{
${ }^{16}$ See Stern (2004) for a review of the literature.

${ }^{17}$ Our approach is equivalent to estimate a Kuznets curve with a three piece spline.

${ }^{18}$ See Appendix C for data definitions and primary sources.
} 
examines the contribution of agriculture and non-agriculture to $\mathrm{CO} 2$ emissions; regression (2) does so for the five economic sectors; and (3) excludes food. Regression (1) shows that the main determinant of $\mathrm{CO} 2$ emissions in all countries is the non-agricultural sector. LAC's nonagricultural sector contributes more air pollution than in other developing and high-income countries. Model (2) indicates that manufactures have the highest coefficient in all countries, but in LAC this effect appears to be higher than in the rest of the sample. The food industries seem to reduce the air-polluting effects of manufactures in all countries. Agriculture has a positive impact in poor and high-income countries, but this effect is negative in LAC, which suggests that increasing the size of agriculture in LAC is associated with lower levels of air pollution. However, when the food industries are excluded, as in model (3), developing-countries agriculture's positive coefficient increases in magnitude, it becomes positive for LAC countries, although the F-test of LAC agriculture's air polluting effect suggests that this effect is not different from zero. In contrast, the impact of manufactures (which include the food industries) becomes smaller in all countries. These results suggest an interesting relationship between the food industries and air pollution: this sector tends to pollute less than other manufacturing industries, but more than commodity agriculture.

Table 5 (b1) focuses on fresh water withdrawals. Model 1 was estimated with a cross section of countries, whereas model 2 uses instrumental variables to control for the endogeneity of the sectorial GDPs. The latter specification shows no significant difference between sectors as a source of pollution (withdrawals) in the poor countries. In LAC and high-income countries the agricultural sector might be a significantly greater source of pollution than the non-agricultural sector. This conclusion is based on the implicit regional coefficients whose F-test are reported at the bottom of the table. 
Table 5 (b2) studies the determinants of water withdrawals by considering the potential effects of all five sectors in regressions 1 and 3; the food sector is excluded from regressions 2 and 4 . The explanatory variables in regressions 3 and 4 are instrumented by lagged differences of the corresponding sector outputs, thus controlling for contemporaneous endogeneity and the influence of unobserved country-specific characteristics. Model 3 shows that agriculture consumes fresh water regardless of whether the food industries are included in the analysis. In this regression, as well as in model 4 , the impact of agriculture is not different across country groups.

Table 5 (c1) assesses the sectorial determinants of deforestation. The regression coefficients under column 1 are from a cross section of countries, whereas column 2 contains results from an instrumental-variables specification. The coefficients from the latter model are all smaller in absolute value than those derived from model 1, which presumes that sectorial GDPs are exogenous. Also, the Hansen test of the validity of the instruments suggests that the chosen instrumental variables are valid. The main finding is that the main source of deforestation is agriculture. However, this coefficient is not significant for LAC or for the high-income countries. $^{19}$

Table 5 (c2) explores the determinants of deforestation by including all five sectors in regression 1 and 3; food is excluded from models 2 and 4 . In regressions 3 and 4 we instrument our explanatory variables by their lagged differences. Regression 3 shows that for the reference group agriculture is a determinant of deforestation, while for LAC and the high-income countries this variable results not significant. For LAC, the food industries appear to be contributing to

\footnotetext{
${ }^{19}$ The p-value of the F-test for the significance of the high-income countries' coefficient is not reported.
} 
deforestation as well as for the high-income countries and industry minus manufacturing. The manufactures sector decreases deforestation for LAC and high income countries. ${ }^{20}$

\section{The Effect of Agriculture on Macroeconomic Volatility}

This section studies the sectorial determinants of macroeconomic volatility. The relationship between macroeconomic volatility has been studied in the seminal paper of Ramey and Ramey (1995) and Hnatkovska and Loayza (2003) among others. Ramey and Ramey find that volatility reduces economic growth, but they do not study the reverse causality between volatility and growth whereas Hnatkovska and Loayza do, who also find a negative relationship between economic growth and volatility.

Hnatkovska and Loayza (2003) consider that volatility is determined by the standard deviation of the inflation rate, real exchange rate misalignment, the standard deviations of terms of trade shocks and the frequency of banking crisis. We follow a different and, to our understanding, novelty venue. As we mention, we will study whether the productive structure has an impact on GDP growth volatility.

To measure volatility we estimate the standard deviation of the GDP's growth rate over four periods of ten years, covering the period 1960-99. With this mini-panel we regress volatility against the average sector outputs using fixed effects. As sectoral outputs are also included in total GDP we instrument the sectoral outputs by the difference in the initial values of the sectoral outputs. We use two lags of this difference set of instruments. We report both instrumented and without instruments regression.

Table 6 shows the descriptive statistics of our database. These data show that agricultural GDP is more volatile than non-agricultural GDP across regions and decades. Agricultural GDP is

\footnotetext{
${ }^{20}$ The test of significance of the effects of the various sectors in the high-income countries is not reported.
} 
most volatile in the case of poor non-LAC countries followed by LAC and high-income countries. This pattern is closely followed with some exceptions for the whole GDP and nonagricultural GDP.

Table 7 presents results from the fixed effects IV and fixed effects without instruments estimators. The results indicate that agriculture and not-agricultural outputs reduce volatility in poor non-LAC and LAC countries. In high-income countries, the coefficients indicate that agriculture contributes to volatility while non-agricultural output decreases it.

The results indicate that the volatility-reducing effect of the non-agricultural sector increases with the level of income for this elasticity is smaller in magnitude for poor-non LAC countries, followed by LAC and high-income countries. The elasticity that captures the effect of agriculture on volatility follows the opposite pattern. The first set of results is consistent with existing analyses of the relationship between economic development and diversification. Imbs and Wacziarg (2003) and Klinger and Lederman (2004) find a consistent pattern related to stages of diversification, based on production, employment, and export data. This pattern follows an inverted $U$ curve with respect to the level of development, whereby countries seem to reach a pinnacle in terms of diversification around $\$ 9,000-10,000$ dollars of GDP per capita measured in purchasing-power parity terms. Thus our results concerning the agricultural sector are consistent with the finding that poor countries' growth is associated with greater diversification, which in turn reduces macroeconomic volatility. In contrast, the results for the non-agricultural sector seem puzzling in the light of Imbs and Wacziarg (2003), although it is plausible that the agricultural specialization effects predominate over other diversification effects, especially given the fact that our estimated coefficients are quite small indeed. In other words, it is also possible that the Imbs and Wacziarg results might not hold for all economic activities. 


\section{Concluding Remarks: The Contribution of Agriculture and Non-Agriculture to National Welfare}

We studied the causal feedback effects across agricultural and non-agricultural GDP. The results indicate that agriculture contributes to the development of the non-agricultural sector, but there is significant heterogeneity across regions. In the case of LAC, this impact appears to be slightly weaker than in the case of other poor countries. Regarding the impact of non-agricultural output on agriculture, we found a predominant resource-pull effect in non-LAC developing and high-income countries that attracts resources to the non-agricultural sector.

Regarding the effect of agriculture on incomes of poor households, the econometric evidence refutes the conventional wisdom. Our results indicate that richer quintiles benefit more from advances in agricultural labor productivity than the poorest households. The paper also examined the impact of agricultural output and other sectors of economic activity on three environmental outcomes. The empirical findings suggest that the sector environmental effects vary across regions. In LAC, agriculture is environmentally neutral, except in the case of water withdrawals. Finally, macroeconomic volatility is significantly affected by the size of the agricultural and non-agricultural sectors in all three groups of countries. The results indicate that the impact of the non-agricultural sector in decreasing macroeconomic volatility increases with the level of income, whereas the elasticity that captures the impact of agriculture in macroeconomic volatility follows the opposite pattern.

These results provide the necessary ingredients to calculate the welfare elasticity with respect to agricultural and non-agricultural output. Equation (3) in Section I shows that this elasticity depends on the econometrically estimated elasticities, on the share of each sector in national GDP, and on current environmental outcomes. Our estimates of the sector welfare 
elasticities are reported in Table 8 . The first set of calculations (row 8 in Table 8) utilizes equal weights for GDP per capita, average income of the bottom quintile, the environmental index, and volatility. The second set of calculations (row 9 Table 8) reports the welfare elasticities assuming that GDP per capita carries $40 \%$ of the weight. These calculations use statistically significant elasticities for each group of countries, whereby the significance was derived from the F-tests of the sum of the elasticity associated with the reference group plus the coefficients on the variables interacted with the corresponding regional dummy variables. ${ }^{21}$

The elasticities in Table 8 suggest that national welfare in high-income countries is best served through non-agricultural growth. This conclusion is supported by the reported pair of sector welfare elasticities, regardless of the assumptions concerning the weights in the national welfare function. Indeed, agricultural growth decreases welfare in these countries. Developing countries' welfare is also best served by non-agricultural development, although the contribution of agriculture is positive and relatively larger than its GDP share. In non-LAC developing countries the ratio between the welfare gains due to non-agricultural growth over the welfare gains due to agricultural growth is 1.67 . When the overall level of development predominates in the national welfare function, then the marginal welfare gains from non-agricultural development are much larger than the gains from agricultural development, indeed the ratio between them is 2.62. In LAC, the ratio between the welfare gains due to non-agricultural growth over the welfare gains due to agricultural growth is 3.5 . When the overall level of development predominates in the national welfare function, the ratio between the welfare gains due to nonagricultural growth over the welfare gains due to agricultural growth is 3.6 , slightly greater than in the previous case.

\footnotetext{
${ }^{21}$ We use elasticities with a significance level of $10 \%$ or higher.
} 
The ratios between the relative contributions to welfare and the sectorial GDP ratios are shown in rows 11 and 12 of Table 8 . These ratios measure the welfare contribution per percentage point of national GDP for each sector. A ratio equal to one implies that the contribution of each sector is proportional to its GDP share, whereas a ratio greater than one implies that the contribution of agriculture to national welfare is more than proportional to its relative GDP share. ${ }^{22}$

For LAC these ratios are close to 2, thus implying that LAC's relative agricultural contribution to national welfare has been about twice its GDP share of $12 \%$. From the evidence in Table 7 it is clear that this result comes from the positive effect of agriculture on the rest of the economy, which also enhances agriculture's poverty-reducing effect. For the other developing countries the ratios are 2 and 1.35. These also come from the positive effect of agricultural growth on the rest of the economy, but the magnification of agriculture's effect on development is relatively smaller than in LAC countries due to the fact that agriculture's GDP share is higher than in LAC. The high-income countries' negative ratios indicate that agricultural growth entails welfare losses. This is due primarily to the fact that agricultural output in developed countries has a net resource-pull effect on the non-agricultural sector, which thus reduces the contribution of agriculture to national welfare. ${ }^{23}$

Since policymakers are interested in maximizing national welfare, these calculations have important policy implications, for they go to the core of policy decisions regarding public sector investments or incentives for private investment across sectors, budget allocations for publicly

\footnotetext{
${ }^{22}$ An alternative interpretation of this ratio is that represents the relative "welfare yields" between agriculture and non-agriculture, understanding as "welfare yield" the percentage change in welfare per point of GDP share.

${ }^{23}$ For the reported welfare elasticities we have used the elasticities reported in Table 2(b) in specifications (1) and (2). Given that although we can not reject the absence of second order serial correlation at a five percent confidence level for those specifications, we replicated Table 8 using the elasticities of specifications (3) and (4). In general we do not find significant departures in the results, although there are some for poor non-LAC countries. This robustness exercise can be obtained upon request from the authors.
} 
supported research and extension services (or R\&D subsidies for non-agricultural activities), or the burden of taxation borne by different sectors (Johnston and Mellor 1961).

For LAC countries, however, there are trade-offs in spite of the fact that agriculture has positive spillover plus multiplier effects on the rest of the average LAC economy. In particular, agriculture is not as pro-poor when contrasted to non-agricultural growth (row 2, Table 8). There seem to be two broad policy paths for the average LAC economy. One is to maintain a sectorneutral tax burden, including neutral trade policies, combined with important public investments to stimulate agricultural productivity growth such as $\mathrm{R} \& \mathrm{D}$ subsidies, plus public investments in education and infrastructure aimed at facilitating the mobility of human capital out of agriculture into off-farm and perhaps even urban economic activities. This strategy could also be complemented by public investments, subsidies, and/or regulatory (labor reforms) designed to enhance the linkages between agricultural commodity production and its upstream food processing industries. The latter is justified by our finding that the positive externalities of agriculture in LAC might be greater when it includes these upstream industries. Another alternative is to implement social and economic reforms that will increase the poverty-reducing effects of agricultural growth. Indeed, historically land reforms in LAC have been justified as means to correct glaring social inequalities in incomes and land ownership. Nonetheless, given the long history of failed land reforms (Deininger 2003), combined with the fact that LAC's low poverty-reducing effects of agriculture are not statistically significantly different from those of other countries, our view is that the first alternative is preferable. 


\section{References}

Aquaye, K.A., Julian Alston, and Philip Pardey (2003). "Port-War Productivity Patterns in U.S. agriculture: Influences of Aggregation Procedures in a State-Level Analysis." American Journal of Agricultural Economics 85(1):59-80.

Arellano, Manuel (2003). Panel Data Econometrics. New York: Cambridge University Press.

Arellano, Manuel, and Stephen Bond (1991). "Some Tests of Especification for Panel Data: Monte Carlo Evidence and an Application to Employment Equations." Review of Economic Studies 58(2): 277-97.

Arellano, Manuel, and Olimpia Bover (1995). "Another look at the Instrumental Variable Estimation of Error Component Models." Journal of Econometrics 68:29-51.

Baltagi, Badi H (2002). Recent developments in the econometrics of panel data. 2 vols. Elgar Reference Collection. International Library of Critical Writings in Econometrics, vol. 9. Cheltenham, U.K. and Northampton, Mass.: Elgar; distributed by American International Distribution Corporation, Williston, VT.

Bernard, Andrew, and Charles Jones (1996). "Comparing Apples to Oranges: Productivity Convergence and Measurement across Industries and Countries." American Economic Review 86(5): 1216-1238.

Caselli, Francesco (2004). "Accounting for Cross Country Income Differences." Forthcoming in the Handbook of Economic Growth.

Chenery, H. B. and M. Syrquin (1975). Patterns of Development. 1950-1970. Oxford University Press, London.

Colburn, Forrest (1993). "Exception to the Urban Bias in Latin America: Cuba and Costa Rica." Journal of Development Studies 29:60-78 July.

Cole, Mathew (2003). "Development, trade, and the environment: how robust is the Environmental Kuznets Curve?" Environment and Development Economics 8:557-80.

Copeland, Brian and Scott Taylor (2004). "Trade, Growth and the Environment." Journal of Economic Literature 42, March, pp:7-71.

Deininger, Klaus (2003). Land Policies for Growth and Poverty Reduction. Washington D.C. World Bank.

Dollar, D. and A. Kraay (2002), "Growth is Good for the Poor", Journal of Economic Growth, 7(3):195-225.

Gallup, J, S. Radelet, and A. Warner (1997), "Economic Growth and the Income of the Poor"prepared for CAER II Project, Harvard Institute for International Development.

Gardner, Bruce (2002). American Agriculture in the Twentieth Century: How it flourished and what it cost. Harvard University Press, Cambridge, Massachusets.

Granger C. (1969). " Investigating Causal Relationships by Econometric Models and CrossSpectral Methods.” Econometrica 37:424-38.

Griliches, Zvi (1963a) "The Sources of Measured Productivity Growth: United States Agriculture, 1940-1960." Journal of Political Economy 71(4):331-46.

Griliches, Zvi (1963b) "Estimates of the Aggregate Agricultural Production Function from Cross-Sectional Data.” Journal of Farm Economics 45:419-28.

Griliches, Zvi (1964).’Research Expenditures, Education, and the Aggregate Agricultural Production Function." American Economic Review, Vol. 54, No. 6. (Dec., 1964), pp. 961-974. 
Grossman, Gene and Alan Krueger (1995). "Economic Growth and the Environment." Quarterly Journal of Economics, May:353-357.

Hayami, Yuyiro and Vernon Ruttan (1970). "Agricultural Productivity Differences among Countries.” American Economic Review, 60(5), pp:895-911.

Hayami, Yujiroand and Wernon Ruttan (1985). Agricultural Development. The Johns Hopkins University Press, Baltimore and London.

Hirschman, Albert (1958). The Strategy of Economic Development. Yale University Press, New Haven.

Hnatcovska, Viktoria and Loayza Norman (2003). "Volatility and Growth." World Bank Working Paper 3184.

Houthakker, H. S. (1955-56). "The Pareto Distribution and the Cobb-Douglas Production Function in Activity Analysis." Review of Economic Studies 23(1):27-31

Ims, Jean and Wacziarg (2003). "Stages of Diversification." American Economic Review 93(1):63-86.

Johnson, Gale (1997), "Agriculture and the Wealth of Nations." American Economic Review, Papers and Proceedings 87(2):1-12, May.

Johnston, Bruce, and John Mellor (1961), "The role of Agriculture in Economic Development." American Economic Review 51(4):566-593.

Jorgenson, Dale (1961), "The Development of the Dual Economy." The Economic Journal, 71(282):309-334, June.

Klinger, Bailey and Daniel Lederman (2004). "Discovery and Development: An Empirical Exploration of 'New Products'.” World Bank Working Paper 3450, November 2004.

Larson, Donald, and Yair Mundlak (1997), "On the Intersectorial Migration of Agricultural Labor." Economic Development and Cultural Change, 45(2):295-319, January.

Martin, Will, and Devanish Mitra (2001). "Productivity Growth and Convergence in Agriculture and Manufacturing," Economic Development and Cultural Change, 49(2), pp: 403-21.

Prebish, Raul (1950). The Economic Development of Latin America and its Pricipal Problems, UN Department of Economic Affairs, Lake Success, NY.

Ramey G, and V. Ramey (1995). "Cross-Country Evidence on the Link Between Volatility and Growth." American Economic Review 85(5):1138-1151.

Ravallion M. and G. Datt (1996). "How important to India's Poor is the Sectorial Composition of Economic Growth?" The World Bank Economic Review 10(1):1-25.

Shafik, N. (1994). "Economic Development and Environmental Quality: An Econometric Analysis." Oxford Economic Papers, 46:757:773.

Stern, David (2004). "The rise and Fall of the Environmental Kuznets Curve." World Development 32(8):1419-1439.

Timmer, Peter (2002) "Agriculture and Economic Development." Handbook of Agrcultural Economics, Volume 2. Eds. Bruce Gardner and G. Rausser.

Varshney, Ashutosh (1993) "Introduction: Urban Bias in Perspective." Journal of Development Studies 29:3-22 July 
Figure 1

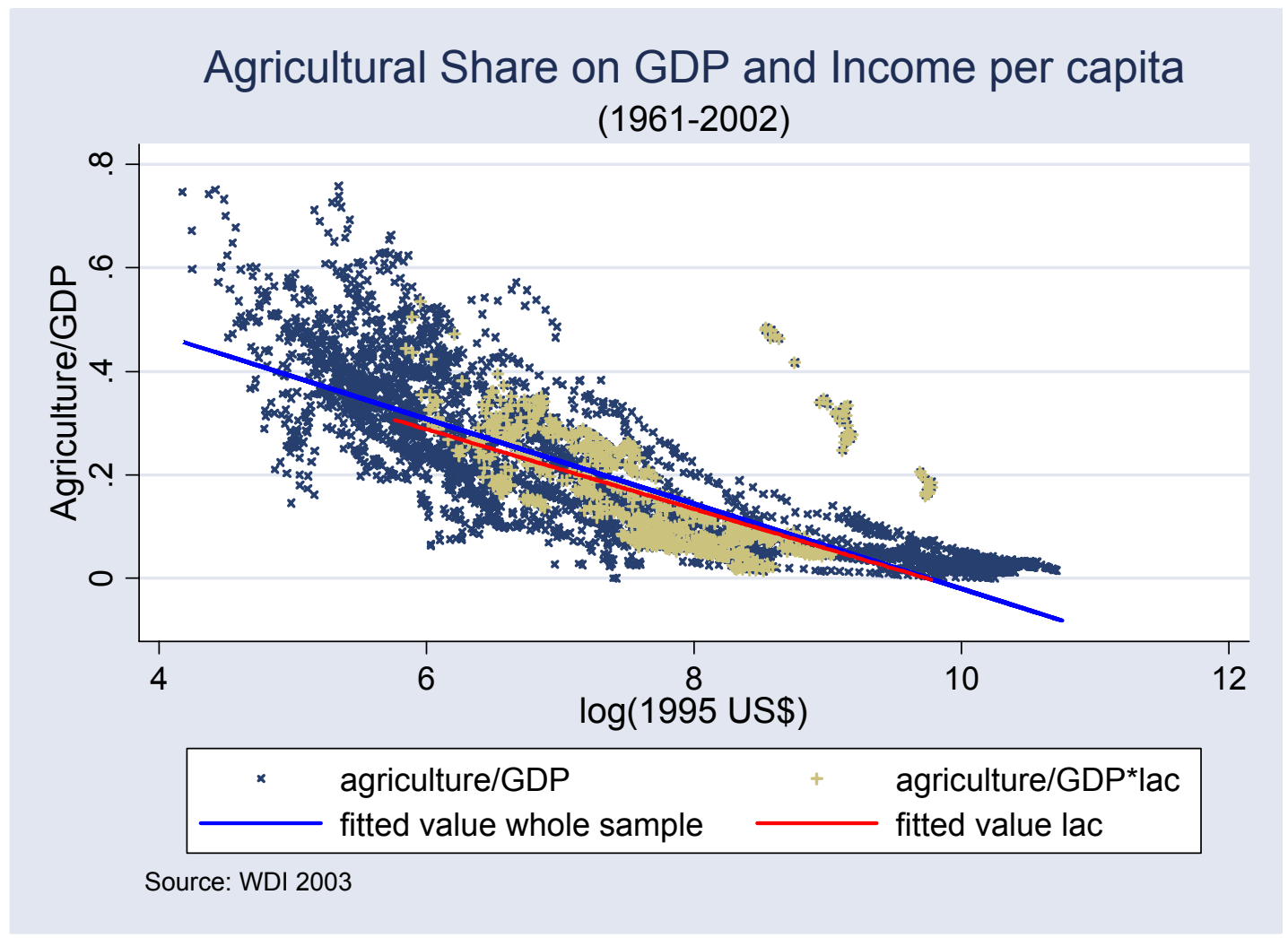


Table 1. Regression Results: The Chenery-Syrquin Relationship Holds across the Globe (Dependent variable: agricultural GDP share; various specifications and estimation techniques)

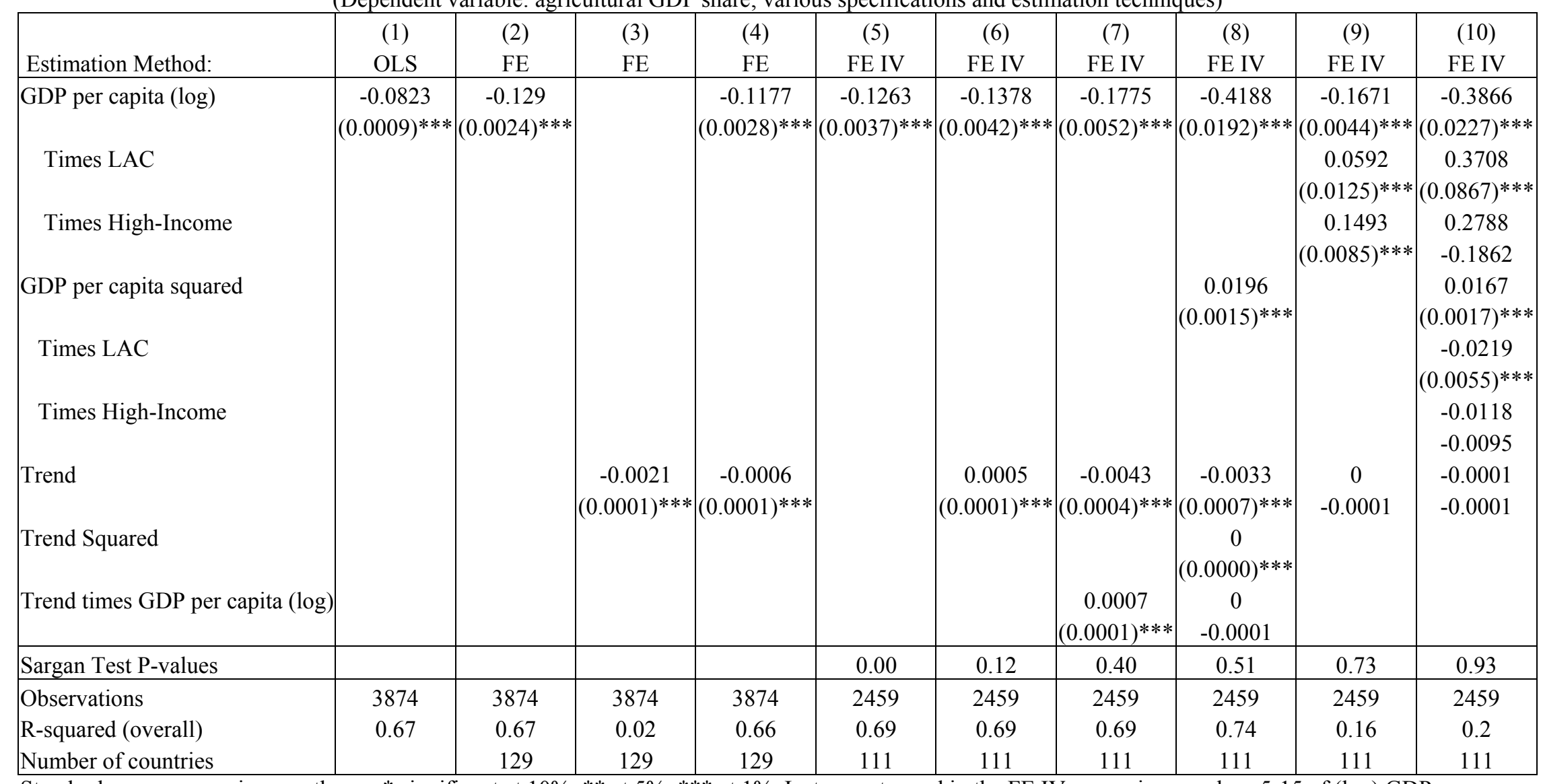

Standard errors appear in parentheses. * significant at 10\%; ** at 5\%; *** at 1\%. Instruments used in the FE IV regressions are lags 5-15 of (log) GDP per capita. 
Table 2 (a). Impact of Agricultural Growth on Non Agricultural Growth

(1960-2000; 5-year periods)

\begin{tabular}{|l|c|c|c|c|c|c|}
\hline & $\begin{array}{c}(1) \\
\text { Growth of NA } \\
\text { Pooled }\end{array}$ & $\begin{array}{c}\text { Growth of NA } \\
\text { Pooled }\end{array}$ & $\begin{array}{c}\text { Growth of NA } \\
\text { Pooled }\end{array}$ & $\begin{array}{c}\text { (4) } \\
\text { Growth of NA } \\
\text { F.E. }\end{array}$ & $\begin{array}{c}(5) \\
\text { Growth of NA } \\
\text { F.E. }\end{array}$ & $\begin{array}{c}(6) \\
\text { Growth of NA } \\
\text { F.E. }\end{array}$ \\
\hline Growth of Agr & 0.4738 & & 0.3551 & 0.3182 & & 0.2899 \\
& $(0.0474)^{* * *}$ & & $(0.0506)^{* * *}$ & $(0.0492)^{* * *}$ & & $(0.0523)^{* * *}$ \\
Growth of Agr (t-1) & & 0.1841 & 0.1741 & & 0.0288 & 0.0999 \\
& & $(0.0477)^{* * *}$ & $(0.0457)^{* * *}$ & & -0.0513 & $(0.0513)^{*}$ \\
\hline R-squared & 0.13 & 0.03 & 0.11 & 0.07 & 0 & 0.07 \\
Observations & 684 & 555 & 555 & 684 & 555 & 555 \\
Number of countries & 129 & 121 & 121 & 129 & 121 & 121 \\
\hline
\end{tabular}

Standard errors appear in parentheses.

* significant at $10 \%$;* significant at $5 \%$; ** significant at $1 \%$. Intercepts are not reported.

Table 2 (b). Impact of Agricultural Growth on Non Agricultural Growth

(1960-2000; 5-year periods)

\begin{tabular}{|c|c|c|c|c|c|c|}
\hline & (1) & (2) & (3) & (4) & (5) & (6) \\
\hline & Growth of NA II & Growth of NA II & Growth of NA I & Growth of NA II & Growth of NA I & I Growth of NA II \\
\hline & Pooled & Pooled & Pooled & F.E. & F.E. & F.E. \\
\hline $\begin{array}{l}\text { Growth of Agr II } \\
\text { Growth of Agr II (t-1) }\end{array}$ & $\begin{array}{c}0.5508 \\
(0.0710)^{* * *}\end{array}$ & $\begin{array}{c}0.4427 \\
(0.1001)^{* * *}\end{array}$ & $\begin{array}{c}0.4725 \\
(0.0827)^{* * *} \\
0.4085 \\
(0.0927)^{* * *} \\
\end{array}$ & $\begin{array}{c}0.4212 \\
(0.0720)^{* * *}\end{array}$ & $\begin{array}{c}0.2803 \\
(0.1104)^{* *}\end{array}$ & $\begin{array}{c}0.351 \\
(0.0920)^{* * *} \\
0.3532 \\
(0.1067)^{* * *}\end{array}$ \\
\hline R-squared & 0.18 & 0.1 & 0.23 & 0.15 & 0.05 & 0.14 \\
\hline Observations & 271 & 186 & 186 & 271 & 186 & 186 \\
\hline Number of countries & 75 & 56 & 56 & 75 & 56 & 56 \\
\hline
\end{tabular}

Standard errors appear in parentheses.

$*$ significant at $10 \%$;* significant at $5 \% ; * * *$ significant at $1 \%$. Intercepts are not reported.

Table 2 (c). Impact of Non Agricultural Growth on Agricultural Growth

(1960-2000; 5-year periods)

\begin{tabular}{|c|c|c|c|c|c|c|}
\hline Esimation Method: & $\begin{array}{c}(1) \\
\text { Pooled }\end{array}$ & $\begin{array}{c}(2) \\
\text { Pooled } \\
\end{array}$ & $\begin{array}{c}(3) \\
\text { Pooled }\end{array}$ & $\begin{array}{l}(4) \\
\text { F.E. }\end{array}$ & $\begin{array}{l}(5) \\
\text { F.E. }\end{array}$ & $\begin{array}{l}(6) \\
\text { F.E. }\end{array}$ \\
\hline $\begin{array}{l}\text { Growth of Non-Agr. } \\
\text { Growth on Non-Agr (t-1) }\end{array}$ & $\begin{array}{c}0.2693 \\
(0.0270)^{* * *}\end{array}$ & $\begin{array}{c}0.033 \\
(0.03)\end{array}$ & $\begin{array}{c}0.2389 \\
(0.0340)^{* * *} \\
-0.0295 \\
(0.03) \\
\end{array}$ & $\begin{array}{c}0.2208 \\
(0.0341)^{* * *}\end{array}$ & $\begin{array}{c}-0.0967 \\
(0.0396)^{* *}\end{array}$ & $\begin{array}{c}0.2176 \\
(0.0426)^{* * *} \\
-0.0862 \\
(0.0386)^{* *}\end{array}$ \\
\hline \begin{tabular}{|l} 
Observations \\
R-squared \\
Number of countries \\
\end{tabular} & $\begin{array}{l}684 \\
0.13 \\
129 \\
\end{array}$ & $\begin{array}{c}555 \\
0 \\
121 \\
\end{array}$ & $\begin{array}{c}555 \\
0.08 \\
121 \\
\end{array}$ & $\begin{array}{r}684 \\
0.07 \\
129 \\
\end{array}$ & $\begin{array}{r}555 \\
0.01 \\
121 \\
\end{array}$ & $\begin{array}{l}555 \\
0.07 \\
121 \\
\end{array}$ \\
\hline
\end{tabular}

Standard errors appear in parentheses.

* significant at $10 \%$; ** significant at 5\%; *** significant at $1 \%$. Intercepts are not reported.

Table 2 (d). Impact of Non Agricultural Growth on Agricultural Growth

(1960-2000; 5-year periods)

\begin{tabular}{|l|c|c|c|c|c|c|}
\hline & $(1)$ & $(2)$ & $(3)$ & $(4)$ & $(5)$ & $(6)$ \\
Estimation Method: & Pooled & Pooled & Pooled & F.E. & F.E. & F.E. \\
\hline
\end{tabular}




\begin{tabular}{|c|c|c|c|c|c|c|}
\hline $\begin{array}{l}\text { Growth of Non-Agr. II } \\
\text { Growth of Non-Agr. II }\end{array}$ & $\begin{array}{c}0.3321 \\
(0.0428)^{* * *}\end{array}$ & $\begin{array}{c}0.0476 \\
(0.06)\end{array}$ & $\begin{array}{c}0.3223 \\
(0.0562)^{* * *} \\
-0.0532 \\
(0.06)\end{array}$ & $\begin{array}{c}0.3542 \\
(0.0606)^{* * *}\end{array}$ & $\begin{array}{c}-0.136 \\
(0.0770)^{*}\end{array}$ & $\begin{array}{c}0.2209 \\
(0.0790)^{* * *} \\
-0.0824 \\
(0.08)\end{array}$ \\
\hline Observations & 271 & 186 & 186 & 271 & 186 & 186 \\
\hline R-squared & 0.18 & 0 & 0.16 & 0.15 & 0.02 & 0.08 \\
\hline Number of countries & 80 & 56 & 56 & 80 & 56 & 56 \\
\hline
\end{tabular}

Standard errors appear in parentheses .

$*$ significant at 10\%; ** significant at 5\%; *** significant at 1\%. Intercepts are not reported.

Table 3 (a). Impact of Agriculture on Non-Agricultural Growth: Granger Causality Test with Various Estimators (1960-2000; 5-year periods)

\begin{tabular}{|l|c|c|c|}
\hline & Non Agric & Non Agric & Non Agric \\
\hline & Pool & F.E. & Syst GMM \\
& $(1)$ & $(2)$ & $(3)$ \\
\hline Agriculture(t-1) & 0.0431 & 0.1177 & 0.1551 \\
& $(0.0091)^{* * *}$ & $(0.0422)^{* *}$ & $(0.0515)^{* * *}$ \\
Non Agriculture(t-1) & 0.9773 & 0.8679 & 0.8931 \\
& $(0.0066)^{* * * * *}$ & $(0.02750)^{* * * *}$ & $(0.0416)^{* * * *}$ \\
\hline Observations & 601 & 601 & 601 \\
Countries & 128 & 128 & 128 \\
\hline Hansen & & & 0.00 \\
\hline
\end{tabular}

Standard errors appear in parentheses

$*$ significant at 10\%; ** significant at 5\%; *** significant at $1 \%$. Intercepts are not reported.

3 (b). Granger Causality Tests between Agricultural and Non-Agricultural Output: GMM System Estimations with Regional Heterogeneity (1960-200; 5-year periods)

\begin{tabular}{|l|c|c|c|c|c|c|}
\hline & $(1)$ & $(2)$ & $(3)$ & $(4)$ & $(5)$ & $(6)$ \\
\hline & $\begin{array}{c}\text { Non } \\
\text { Agriculture }\end{array}$ & Agriculture & $\begin{array}{c}\text { Non } \\
\text { Agriculture }\end{array}$ & Agriculture & $\begin{array}{c}\text { Non } \\
\text { Agriculture } \\
\text { II }\end{array}$ & $\begin{array}{c}\text { Agriculture } \\
\text { II }\end{array}$ \\
\hline Non Agriculture (t-1) & 0.876 & -0.168 & 0.922 & -0.065 & 0.964 & -0.023 \\
(Poor Countries) & $(0.000)^{* * *}$ & $(0.009)^{* *}$ & $(0.000)^{* * *}$ & $(0.383)$ & $(0.000)^{* * *}$ & $(0.701)$ \\
\hline Non Agriculture (t-1) times & 0.031 & 0.177 & -0.0368 & 0.017 & -0.116 & -0.009 \\
Latin America & $(0.728)$ & $(0.039)^{* *}$ & $(0.605)$ & $(0.837)$ & $(0.125)$ & $(0.874)$ \\
\hline Non Agriculture (t-1) times & 0.213 & 0.140 & 0.214 & -0.007 & 0.214 & 0.094 \\
High Income & $(0.006)^{* * *}$ & $(0.137)$ & $(0.001)^{* * *}$ & $(0.931)$ & $(0.000)^{* * *}$ & $(0.343)$ \\
\hline Agriculture (t-1) & 0.148 & 1.203 & 0.098 & 1.079 & 0.054 & 1.036 \\
(Poor Countries) & $(0.048)^{* *}$ & $(0.000)^{* * *}$ & $(0.173)$ & $(0.000)^{* * *}$ & $(0.368)$ & $(0.000)^{* * *}$ \\
\hline Agriculture (t-1) times & -0.030 & -0.185 & 0.0411 & -0.015 & 0.123 & 0.009 \\
Latin America & $(0.756)$ & $(0.041)^{* *}$ & $(0.588)$ & $(0.849)$ & $(0.112)$ & $(0.880)$ \\
\hline Agriculture (t-1) times & -0.235 & -0.147 & -0.242 & 0.010 & -0.124 & -0.108 \\
High Income & $(0.005)^{* * *}$ & $(0.154)$ & $(0.001)^{* * *}$ & $(0.900)$ & $(0.000)^{* * *}$ & $(0.318)$ \\
\hline
\end{tabular}




\begin{tabular}{|c|c|c|c|c|c|c|}
\hline $\begin{array}{l}\text { Observations } \\
\text { Countries }\end{array}$ & $\begin{array}{l}601 \\
128 \\
\end{array}$ & $\begin{array}{l}601 \\
128 \\
\end{array}$ & $\begin{array}{c}320 \\
80 \\
\end{array}$ & $\begin{array}{c}320 \\
80 \\
\end{array}$ & $\begin{array}{c}320 \\
80 \\
\end{array}$ & $\begin{array}{c}320 \\
80 \\
\end{array}$ \\
\hline Hansen's J-statistics p-values & 0.29 & 0.80 & 0.77 & 0.99 & 0.79 & 0.93 \\
\hline \multicolumn{7}{|c|}{ Regional Coefficients and P-values of F-Tests for Significance of the Sum of the Corresponding Coefficients } \\
\hline \multicolumn{7}{|c|}{ LAC Countries } \\
\hline Non Agriculture (t-1) & $\begin{array}{c}0.907 \\
(0.000)\end{array}$ & $\begin{array}{c}0.009 \\
(0.791) \\
\end{array}$ & $\begin{array}{c}0.885 \\
(0.000)\end{array}$ & $\begin{array}{l}-0.047 \\
(0.111)\end{array}$ & $\begin{array}{c}0.847 \\
(0.000)\end{array}$ & $\begin{array}{l}-0.032 \\
(0.367)\end{array}$ \\
\hline Agriculture (t-1) & $\begin{array}{c}0.118 \\
(0.053)\end{array}$ & $\begin{array}{c}1.017 \\
(0.000)\end{array}$ & $\begin{array}{c}0.139 \\
(0.010) \\
\end{array}$ & $\begin{array}{c}1.063 \\
(0.000) \\
\end{array}$ & $\begin{array}{c}0.177 \\
(0.000)\end{array}$ & $\begin{array}{c}1.045 \\
(0.000)\end{array}$ \\
\hline \multicolumn{7}{|c|}{ High-Income Countries } \\
\hline Non Agriculture (t-1) & $\begin{array}{c}1.089 \\
(0.037) \\
\end{array}$ & $\begin{array}{l}-0.027 \\
(0.546) \\
\end{array}$ & $\begin{array}{c}1.136 \\
(0.000) \\
\end{array}$ & $\begin{array}{l}-0.072 \\
(0.007) \\
\end{array}$ & $\begin{array}{c}1.178 \\
(0.000) \\
\end{array}$ & $\begin{array}{c}0.071 \\
(0.220) \\
\end{array}$ \\
\hline Agriculture (t-1) & $\begin{array}{l}-0.087 \\
(0.040) \\
\end{array}$ & $\begin{array}{c}1.055 \\
(0.000) \\
\end{array}$ & $\begin{array}{r}-0.1447 \\
(0.000) \\
\end{array}$ & $\begin{array}{r}1.089 \\
(0.000) \\
\end{array}$ & $\begin{array}{l}-0.069 \\
(0.000) \\
\end{array}$ & $\begin{array}{c}0.927 \\
(0.000) \\
\end{array}$ \\
\hline
\end{tabular}

Estimations were computed with two-step robust standard errors and Windmeijer's finite sample correction. P values appear in parentheses. * significant at $10 \%$; ** significant at $5 \%$; *** significant at $1 \%$. Intercepts are not reported.

\section{Table 4. Sectorial Determinants of Average Incomes across Household-Income Quintiles: GMM System Estimations with Regional Hetereogeneity}

(1960-2000;5 year panel)

\begin{tabular}{|l|c|c|c|c|c|}
\hline & $(1)$ & $(2)$ & $(3)$ & $(4)$ & $(5)$ \\
& GMM System & GMM System & GMM System & GMM System & GMM System \\
& Q1 & Q2 & Q3 & Q4 & Q5 \\
\hline Income Quintile & 0.3624 & 0.4426 & 0.423 & 0.3832 & 0.4121 \\
& $(0.1578)^{* *}$ & $(0.1270)^{* * *}$ & $(0.1004)^{* * *}$ & $(0.1419)^{* * *}$ & $(0.1003)^{* * *}$ \\
Non-Agric. Output per Worker & 0.6418 & 0.5622 & 0.5566 & 0.5969 & 0.6249 \\
& $(0.1585)^{* * *}$ & $(0.1892)^{* * *}$ & $(0.1046)^{* * *}$ & $(0.1421)^{* * *}$ & $(0.1186)^{* * *}$ \\
\hline Agricultural Output per Worker & -0.1716 & -0.3214 & -0.2512 & -0.2558 & -0.3448 \\
times LAC & $(0.2095)$ & $(0.1341)^{* *}$ & $(0.1622)$ & $(0.1570)$ & $(0.1131)^{* * *}$ \\
Non-Agric. Output per Worker & 0.1303 & 0.2732 & 0.2263 & 0.2392 & 0.3378 \\
times LAC & $(0.1762)$ & $(0.1105)^{* *}$ & $(0.1364)$ & $(0.1285)^{*}$ & $(0.0975)^{* * *}$ \\
\hline Agricultural Output per Worker & -0.2094 & -0.4054 & -0.3878 & -0.4088 & -0.4389 \\
times High-Income & $(0.2438)$ & $(0.2105)^{*}$ & $(0.1586)^{* *}$ & $(0.2016)^{* *}$ & $(0.1393)^{* * *}$ \\
Non-Agric. Output per Worker & 0.2615 & 0.4418 & 0.4286 & 0.4439 & 0.4294 \\
times High-Income & $(0.2102)$ & $(0.1900)^{* *}$ & $(0.1400)^{* * *}$ & $(0.1795)^{* *}$ & $(0.1194)^{* * *}$ \\
\hline Observations & 226 & 226 & 226 & 226 & 226 \\
Countries & 84 & 84 & 84 & 84 & 84 \\
\hline Hansen's J-statistic P-values & 0.87 & 0.68 & 0.84 & 0.95 & 0.96 \\
\hline \multicolumn{7}{|c|}{ Latin America Effect (p-values) } & & \\
\hline Agriculture & 0.10 & 0.01 & 0.06 & 0.01 & 0.00 \\
Non Agriculture & 0.00 & 0.00 & 0.00 & 0.00 & 0.00 \\
\hline & 0.43 & 0.82 & 0.75 & 0.83 & 0.83 \\
\hline Agriculture & 0.00 & 0.00 & 0.00 & 0.00 & 0.00 \\
\hline Non Agriculture & \multicolumn{7}{|c|}{ High Income Effect (p-values) } \\
\hline
\end{tabular}

* significant at $10 \% ; * *$ significant at $5 \% ; * * *$ significant at $1 \%$

All regressions include period dummies and were estimated using Windmeijer's finite sample correction 
and robust standard errors. Intercepts are not reported.

\section{Table 5 (a). Sectorial Determinants of (log) CO2 Emissions: Fixed-Effects Estimations}

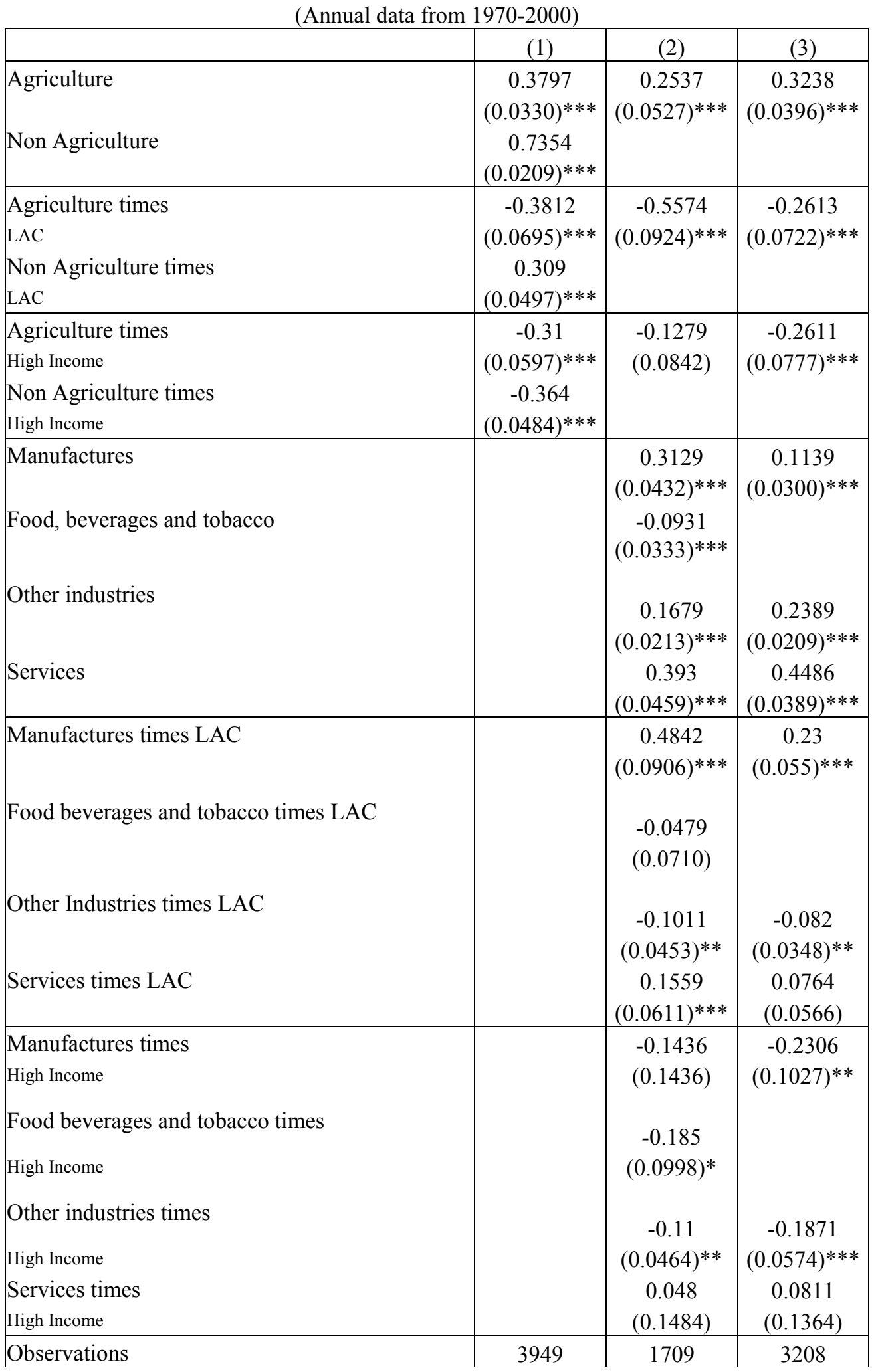




\begin{tabular}{|l|c|c|c|} 
Countries & 167 & 111 & 159 \\
\hline R-squared & 0.55 & 0.72 & 0.60 \\
\hline \multicolumn{4}{|c|}{ LAC Effects P-values } \\
\hline Agriculture & 0.98 & 0.00 & 0.30 \\
Non Agriculture & 0.00 & & \\
Food beverages and tobacco & & 0.03 & \\
Manufactures & & 0.00 & 0.00 \\
Other industries & & 0.10 & 0.00 \\
Services & High-Income Effects P-values \\
\hline \multicolumn{4}{|c|}{0.16} \\
Agriculture \\
Non-Agriculture
\end{tabular}

Standard errors in parentheses

* significant at $10 \%$;* significant at $5 \%$; ** significant at $1 \%$

Table 5 (b1). Sectorial Determinants of (log) Fresh-Water Withdrawals: GMM Cross-Section Estimations for Year 2000 Data

\begin{tabular}{|l|c|c|}
\hline & $(1)$ & $(2)$ \\
& CS & CS IV \\
\hline Agriculture & 0.7112 & 0.6574 \\
& $(0.2155)^{* * *}$ & $(0.2708)^{* *}$ \\
& 0.4067 & 0.6471 \\
& $(0.1889)^{* *}$ & $(0.2430)^{* * *}$ \\
\hline Agriculture times LAC & -0.1968 & 0.7465 \\
& $(0.4255)$ & $(0.5694)$ \\
Non-Agriculture times LAC & 0.1819 & -0.6754 \\
& $(0.3872)$ & $(0.5239)$ \\
\hline Agriculture times High-Income & 0.2501 & 0.9978 \\
& $(0.3108)$ & $(0.4706)^{* *}$ \\
Non-Agriculture times High-Income & -0.2737 & -0.9527 \\
& $(0.2798)$ & $(0.4237)^{* *}$ \\
\hline Observations & 95 & 95 \\
\hline Hansen J-statistic P-value & LAC Effect P-values & 0.27 \\
\hline \multicolumn{2}{|c|}{ High Income Effect P-values } \\
\hline Agriculture & 0.18 & 0 \\
Non-Agriculture & 0.08 & 0.95 \\
\hline \multicolumn{2}{|c|}{0.52} & 0.35 \\
\hline Agriculture effect & Non-Agriculture &
\end{tabular}

Robust standard errors appear in parentheses.

Table 5 (b2). Sectorial Determinants of $(\log )$ of Fresh-Water Withdrawals: GMM Cross-Section (CS) Estimations with Year 2000 Data

\begin{tabular}{|l|l|l|l|c|}
\hline & $(1)$ & $(2)$ & $(3)$ & $(4)$ \\
& CS & CS & CS IV & CS IV
\end{tabular}




\begin{tabular}{|c|c|c|c|c|}
\hline Agriculture & 1.0923 & 0.7989 & 1.115 & 0.8053 \\
\hline & $(0.3245)^{* * *}$ & $(0.2026)^{* * *}$ & $(0.5091)^{* *}$ & $(0.4713) *$ \\
\hline Manufactures & $\begin{array}{c}0.3024 \\
(0.4700)\end{array}$ & $\begin{array}{c}0.6265 \\
(0.2944)^{* *}\end{array}$ & $\begin{array}{c}0.3632 \\
(1.1629)\end{array}$ & $\begin{array}{c}0.1281 \\
(0.7050)\end{array}$ \\
\hline Fodd, beverages, and tobacco & $\begin{array}{c}-0.2058 \\
(0.4641)\end{array}$ & & $\begin{array}{c}0.4836 \\
(0.7305)\end{array}$ & \\
\hline Other industries & $\begin{array}{c}0.0904 \\
(0.3793)\end{array}$ & $\begin{array}{c}-0.1778 \\
(0.2435)\end{array}$ & $\begin{array}{c}0.8406 \\
(0.6828)\end{array}$ & $\begin{array}{c}0.2028 \\
(1.0666)\end{array}$ \\
\hline Services & $\begin{array}{c}-0.1683 \\
(0.7206) \\
\end{array}$ & $\begin{array}{c}-0.2415 \\
(0.4562) \\
\end{array}$ & $\begin{array}{c}-1.6062 \\
(1.3124) \\
\end{array}$ & $\begin{array}{c}-0.177 \\
(1.7230) \\
\end{array}$ \\
\hline Agriculture times LAC & $\begin{array}{l}-0.4297 \\
(0.5935)\end{array}$ & $\begin{array}{l}-0.1727 \\
(0.5233)\end{array}$ & $\begin{array}{l}-0.5804 \\
(0.6399)\end{array}$ & \begin{tabular}{|c|}
-0.9281 \\
$(0.9659)$
\end{tabular} \\
\hline Manufactures times LAC & $\begin{array}{l}-1.2737 \\
(1.0513)\end{array}$ & $\begin{array}{c}-1.1798 \\
(0.6223)^{*}\end{array}$ & $\begin{array}{c}-0.2987 \\
(1.2587)\end{array}$ & $\begin{array}{c}0.0678 \\
(1.0285)\end{array}$ \\
\hline Food, beverages, tobacco times LAC & $\begin{array}{c}1.2691 \\
(1.3206)\end{array}$ & & $\begin{array}{c}0.6091 \\
(1.2918)\end{array}$ & \\
\hline Other industries times LAC & $\begin{array}{c}0.2802 \\
(0.7485)\end{array}$ & $\begin{array}{c}0.5958 \\
(0.4651)\end{array}$ & $\begin{array}{c}-1.3909 \\
(0.9212)\end{array}$ & $\begin{array}{c}1.1228 \\
(1.4322)\end{array}$ \\
\hline Services times LAC & $\begin{array}{c}0.2121 \\
(1.1136)\end{array}$ & $\begin{array}{c}0.724 \\
(0.6046) \\
\end{array}$ & $\begin{array}{c}1.5879 \\
(1.7810)\end{array}$ & $\begin{array}{c}-0.24 \\
(2.0521)\end{array}$ \\
\hline Agriculture times High-Income & $\begin{array}{c}-0.549 \\
(1.8642)\end{array}$ & $\begin{array}{l}-0.1062 \\
(1.2328)\end{array}$ & $\begin{array}{c}-0.4704 \\
(0.7302)\end{array}$ & $\begin{array}{l}-1.1326 \\
(2.1289)\end{array}$ \\
\hline Manufactures times High-Income & $\begin{array}{c}0.1869 \\
(1.0790)\end{array}$ & $\begin{array}{c}0.697 \\
(0.9608)\end{array}$ & $\begin{array}{c}0.6088 \\
(1.0917)\end{array}$ & $\begin{array}{c}1.3669 \\
(1.6931)\end{array}$ \\
\hline $\begin{array}{l}\text { Food, beverages, tobacco times } \\
\text { High-Income }\end{array}$ & $\begin{array}{l}-0.7224 \\
(0.9875)\end{array}$ & & $\begin{array}{c}-1.3185 \\
(0.7527)^{*}\end{array}$ & \\
\hline Other industries times High-Income & $\begin{array}{l}-0.7976 \\
(1.8787)\end{array}$ & $\begin{array}{c}0.4937 \\
(1.1276)\end{array}$ & $\begin{array}{c}-1.4226 \\
(0.8105)^{*}\end{array}$ & $\begin{array}{l}-0.0794 \\
(1.7910)\end{array}$ \\
\hline Services times High-Income & $\begin{array}{r}1.6525 \\
(4.9807) \\
\end{array}$ & $\begin{array}{l}-1.0624 \\
(2.7385) \\
\end{array}$ & $\begin{array}{c}2.3089 \\
(1.5576) \\
\end{array}$ & \begin{tabular}{|c|}
-0.2421 \\
$(4.0693)$ \\
\end{tabular} \\
\hline Observations & 47 & 96 & 47 & 96 \\
\hline Hansen J-statistic P-value & & & 0.49 & 0.10 \\
\hline LAC F & Effects P-val & lues & & \\
\hline Agriculture & 0.18 & 0.22 & 0.23 & 0.90 \\
\hline Manufactures & 0.42 & 0.41 & 0.95 & 0.81 \\
\hline Food, beverages and tobacco & 0.41 & & 0.35 & \\
\hline Other industries & 0.52 & 0.29 & 0.30 & 0.28 \\
\hline Services & 0.95 & 0.36 & 0.98 & 0.76 \\
\hline
\end{tabular}

Robust standard errors appear in parentheses.

* significant at $10 \%$; * significant at $5 \%$; ** significant at $1 \%$

Table 5(c1). Sectorial Determinants of Deforestation: GMM Cross-Section (CS) Estimations

(Deforestation $=$ change in log of forest area between 1990 and 2000)

\begin{tabular}{|c|c|c|}
\hline & $(1)$ & $(2)$ \\
& CS & CS IV \\
\hline
\end{tabular}




\begin{tabular}{|l|c|c|}
\hline Agriculture & 0.0511 & 0.0436 \\
Non-Agriculture & $(0.0144)^{* * *}$ & $(0.0190)^{* *}$ \\
& -0.0612 & -0.0451 \\
$(0.0142)^{* * *}$ & $(0.0176)^{* *}$ \\
\hline Agriculture times LAC & 0.0182 & -0.0392 \\
Non-Agriculture times LAC & $(0.0421)$ & $(0.0530)$ \\
& -0.0136 & 0.0372 \\
\hline Agriculture times High-Income & $(0.0376)$ & $(0.0481)$ \\
\hline Non-Agriculture times High-Income & -0.0801 & -0.062 \\
& $(0.0257)^{* * *}$ & $0.0283)^{* *}$ \\
\hline Observations & 0.0707 & $(0.0249)^{* *}$ \\
\hline Hansen's J-statistic P-value & $(0.0225)^{* * *}$ & 114 \\
\hline \multicolumn{2}{|c|}{ LAC Effects P-values } & 0.48 \\
\hline Agriculture & 114 & 0.07 \\
\hline Non-Agriculture & 0.04 & 0.87 \\
\hline \multicolumn{2}{|c|}{ High-Income P-values } \\
\hline Agriculture & 0.16 & 0.38 \\
\hline Non-Agriculture & 0.61 & 0.69 \\
\hline
\end{tabular}

Robust standard errors appear in parentheses.

Table 5(c2). Sectorial Determinants of Deforestation: GMM Cross-Section Estimations

(Deforestation $=$ change in log of forest area between 1990 and 2000)

\begin{tabular}{|l|c|c|c|c|}
\hline & $(1)$ & $(2)$ & $(3)$ & $(4)$ \\
& CS & CS & CS IV & CS IV \\
\hline Agriculture & 0.0395 & 0.0433 & 0.0686 & 0.0828 \\
& $(0.0253)$ & $(0.0150)^{* * *}$ & $(0.0235)^{* * *}$ & $(0.0291)^{* * *}$ \\
Manufactures & 0.0154 & -0.0612 & 0.0002 & -0.1074 \\
& $(0.0636)$ & $(0.0251)^{* *}$ & $(0.0811)$ & $(0.0845)$ \\
Food, beverages, tobacco & & & & \\
Other industries & -0.0018 & & 0.004 & $(0.1012)$ \\
Services & $(0.0936)$ & & & \\
& & & & \\
Agriculture times LAC & -0.0691 & -0.0129 & -0.0058 & -0.0234 \\
& $(0.0316)^{* *}$ & $(0.0187)$ & $(0.0657)$ & $(0.0780)$ \\
Manufactures times LAC & -0.0011 & 0.0345 & -0.0766 & 0.0596 \\
Food, beverages, tobacco times & $(0.0503)$ & $(0.0346)$ & $(0.0873)$ & $(0.1306)$ \\
LAC & -0.0737 & 0.0074 & -0.0738 & -0.0369 \\
Other industries times LAC & $(0.0593)$ & $(0.0362)$ & $(0.0527)$ & $(0.0690)$ \\
& -0.1286 & 0.0165 & -0.1722 & 0.0965 \\
& $(0.1400)$ & $(0.0606)$ & $(0.1149)$ & $(0.1121)$ \\
& 0.0828 & & 0.1717 & $(0.1272)$ \\
\end{tabular}




\begin{tabular}{|l|c|c|c|c|} 
Services times LAC & -0.0339 & 0.0187 & -0.0079 & 0.1388 \\
& $(0.0765)$ & $(0.0655)$ & $(0.1006)$ & $(0.1865)$ \\
\hline Agriculture times High-Income & -0.0534 & -0.0639 & -0.0805 & -0.1019 \\
Manufactures times High-Income & $(0.0255)^{* *}$ & $(0.0197)^{* * *}$ & $(0.0243)^{* * *}$ & $(0.0338)^{* * *}$ \\
& 0.1034 & 0.0228 & 0.1145 & 0.0684 \\
Food, beverages, tobacco times & $(0.0525)^{* *}$ & $(0.0548)$ & $(0.0743)$ & $(0.0914)$ \\
High-Income & 0.0465 & & 0.0344 & \\
Other industries times & $(0.1038)$ & & $(0.1053)$ & \\
High-Income & 0.1294 & 0.0157 & 0.0577 & 0.0122 \\
Services times High-Income & $(0.0357)^{* * *}$ & $(0.0298)$ & $(0.0675)$ & $(0.0786)$ \\
& -0.2112 & 0.0196 & -0.1186 & 0.0149 \\
\hline Observations & $(0.0929)^{* *}$ & $(0.0781)$ & $(0.1001)$ & $(0.1326)$ \\
\hline Hansen's J-statistic P-values & 51 & 119 & 51 & 119 \\
\hline \multicolumn{5}{|c|}{ LAC Effects P-values } \\
Agriculture & 0.49 & 0.12 & 0.11 & 0.70 \\
Manufactures & 0.41 & 0.46 & 0.03 & 0.90 \\
Food, beverages and Tobacco & 0.44 & & 0.01 & \\
Other industries & & & 0.06 & 0.11 \\
Services & 0.33 & 0.46 & 0.13 & 0.15 \\
\hline
\end{tabular}

Robust standard errors in parentheses

* significant at $10 \% ; *$ significant at $5 \%$; ** significant at $1 \%$

Table 6. Volatility of Economic Growth across Sectors and Regions by Decades (annual data from 1960-2000)

\begin{tabular}{|c|c|c|c|c|}
\hline Decade & $60 ' s$ & 60's & 70 's & 70 's \\
\hline & Obs & Mean & Obs & Mean \\
\hline Standard Deviation of Agricultural GDP Growth & 590 & 0.065 & 850 & 0.079 \\
\hline LAC Countries & 190 & 0.058 & 190 & 0.057 \\
\hline High-Income Countries & 50 & 0.061 & 200 & 0.066 \\
\hline Other Developing Countries & 350 & 0.070 & 460 & 0.094 \\
\hline Standard Deviation of Non-Agricultural GDP Growth & $\mathbf{5 9 0}$ & 0.056 & 850 & 0.053 \\
\hline High-Income Countries & 50 & 0.028 & 200 & 0.026 \\
\hline LAC Countries & 190 & 0.031 & 190 & 0.048 \\
\hline Other Developing Countries & 350 & 0.074 & 460 & 0.067 \\
\hline Standard Deviation of Total GDP Growth & 960 & 0.042 & 1020 & 0.045 \\
\hline High-Income Countries & 220 & 0.023 & 230 & 0.028 \\
\hline LAC Countries & 240 & 0.035 & 240 & 0.039 \\
\hline Other Developing Countries & 500 & 0.053 & 550 & 0.054 \\
\hline Decade & 80's & 80's & 90 's & 90's \\
\hline & Obs & Mean & Obs & Mean \\
\hline Standard Deviation of Agricultural GDP Growth & 1090 & 0.076 & 1290 & 0.080 \\
\hline High-Income Countries & 200 & 0.071 & 200 & 0.058 \\
\hline LAC Countries & 200 & 0.072 & 210 & 0.052 \\
\hline
\end{tabular}




\begin{tabular}{|l|c|c|c|c|}
\hline Other Developing Countries & 690 & 0.078 & 880 & 0.092 \\
\hline \multicolumn{4}{|l|}{$\mid$} \\
\hline Standard Deviation of Non-Agricultural GDP Growth & $\mathbf{1 0 9 0}$ & $\mathbf{0 . 0 4 6}$ & $\mathbf{1 2 9 0}$ & $\mathbf{0 . 0 5 7}$ \\
\hline High-Income Countries & 200 & 0.020 & 200 & 0.019 \\
\hline LAC Countries & 200 & 0.055 & 210 & 0.054 \\
\hline Other Developing Countries & 690 & 0.051 & 880 & 0.066 \\
\hline \multicolumn{4}{|l|}{$\mid$} \\
\hline Standard Deviation of Total GDP Growth & $\mathbf{1 2 6 0}$ & $\mathbf{0 . 0 4 0}$ & $\mathbf{1 4 3 0}$ & $\mathbf{0 . 0 5 0}$ \\
\hline High-Income Countries & 230 & 0.021 & 230 & 0.020 \\
\hline LAC Countries & 240 & 0.046 & 240 & 0.041 \\
\hline Other Developing Countries & 790 & 0.044 & 960 & 0.059 \\
\hline
\end{tabular}

Table 7. Sectorial Determinants of GDP-Growth Volatility, 1960-1999

(Dependent variable: Standard deviation of total-GDP growth by decades)

\begin{tabular}{|l|c|c|}
\hline & FE IV & FE \\
\hline Agriculture & -0.047 & -0.032 \\
Non Agriculture & $(0.013)^{* * *}$ & $(0.018)^{*}$ \\
& -0.019 & 0.007 \\
Agriculture times LAC & $(0.011)^{*}$ & $(0.011)$ \\
& 0.008 & 0.017 \\
Non-Agriculture times LAC & $0.011)$ & $(0.016)$ \\
& -0.022 & -0.022 \\
Agriculture times high income & $0.011)^{* *}$ & $(0.016)$ \\
& 0.054 & 0.032 \\
Non-Agriculture times high income & $(0.015)^{* * *}$ & $(0.020)$ \\
& -0.053 & -0.032 \\
\hline Sargan (p-value) & $(0.014)^{* * *}$ & $(0.019)$ \\
\hline Observations & 0.234 & 101 \\
Countries & 101 & 101 \\
\hline \multicolumn{3}{|c|}{ F Test LAC (p-values) } \\
\hline Agriculture & 71 & 71 \\
Non Agriculture & 0.00 & 0.20 \\
\hline \multicolumn{2}{|c|}{0.00} & 0.19 \\
\hline Agriculture test High Income (p-Values) \\
Non Agriculture & 0.08 & 0.92 \\
\hline
\end{tabular}

Note: $*=$ significant at $10 \% ; * *$ at $5 \% ; * * *$ at $1 \%$ 
Table 8. Contributions of Agriculture and Non-Agriculture to National Welfare as of 2000

\begin{tabular}{|c|c|c|c|c|c|c|c|}
\hline & & \multicolumn{2}{|c|}{ LAC } & \multicolumn{2}{|c|}{ High-Income } & \multicolumn{2}{|c|}{ Others } \\
\hline & & Agr & Non-Ag & Agr & Non-Ag & Agr & Non- $A g$ \\
\hline 1 & Contrib thru GDP & 0.22 & 0.88 & -0.05 & 0.97 & 0.34 & 0.74 \\
\hline 2 & Contrib thru Income of the Poor & 0.28 & 0.77 & -0.08 & 0.90 & 0.46 & 0.58 \\
\hline 3 & Contrib thru Air Pollution & -0.02 & -0.18 & 0.03 & -0.29 & -0.06 & -0.08 \\
\hline 4 & Contrib thru Fresh Water With. & -0.21 & 0.00 & -0.25 & 0.00 & -0.09 & -0.06 \\
\hline 5 & Contrib thru Deforestation & 0.00 & 0.00 & 0.00 & 0.00 & -0.04 & 0.05 \\
\hline 6 & Contrib thru Environmental Index $(1 / 3 *((3)+(4)+(5))$ & -0.08 & -0.06 & -0.07 & -0.10 & -0.06 & -0.03 \\
\hline 7 & Contrib thru Macro Volatility & 0.04 & 0.04 & -0.01 & 0.07 & 0.05 & 0.01 \\
\hline 8 & Contrib to National Welfare (eq. Weights: $(1)+(2)+(6)+(7))$ & 0.12 & 0.41 & -0.05 & 0.46 & 0.19 & 0.33 \\
\hline 9 & Contrib to National Welfare (GDP $=40 \%$, others $20 \%$ ) & 0.14 & 0.50 & -0.05 & 0.56 & 0.16 & 0.41 \\
\hline 10 & GDP Share (Sector GDP/Total GDP) & 0.12 & 0.88 & 0.03 & 0.97 & 0.22 & 0.78 \\
\hline 11 & Ratio of relative welfare contrib ratio/GDP ratio (eq. Weights) & 2.12 & & -3.84 & & 2.12 & \\
\hline 12 & Ratio of relative welfare contrib ratio/GDP ratio $(\mathrm{GDP}=40 \%, \ldots)$ & 2.03 & & -3.14 & & 1.35 & \\
\hline & $\begin{array}{l}\text { Memo items } \\
\text { Elasticity of X wrt each sector }\end{array}$ & & & & & & \\
\hline & GDP-Sector & 0.12 & 0.00 & -0.09 & 0.00 & 0.15 & -0.17 \\
\hline & Income of the Poor & 0.19 & 0.77 & 0.00 & 0.90 & 0.36 & 0.64 \\
\hline & Air Pollution & 0.00 & 1.04 & 0.00 & 0.38 & 0.38 & 0.74 \\
\hline & Fresh Water With. & 1.40 & 0.00 & 1.66 & 0.00 & 0.66 & 0.65 \\
\hline & Deforestation & 0.00 & 0.00 & 0.00 & 0.00 & 0.04 & -0.05 \\
\hline & Macro Volatility & -0.039 & -0.041 & 0.01 & -0.07 & -0.05 & -0.02 \\
\hline
\end{tabular}


Appendix A: Samples of Countries Used in the Various Econometric Exercises and Summary Statistics of Agricultural and Non-Agricultural Output and Labor Shares

Descriptive Statistics

(1960-2000)

\begin{tabular}{|l|c|c|c|}
\hline Variable & Obs & Mean & Std. Dev. \\
\hline lac Agricultural Growth & 903 & 0.026 & 0.009 \\
hi Agricultural Growth & 860 & 0.017 & 0.012 \\
pr Agricultural Growth & 3784 & 0.022 & 0.025 \\
Agricultural Growth & 5547 & 0.022 & 0.021 \\
\hline lac Non-Agricultural Growth & 903 & 0.038 & 0.017 \\
hi Non-Agricultural Growth & 860 & 0.032 & 0.014 \\
pr Non-Agricultural Growth & 3784 & 0.037 & 0.047 \\
Non-Agricultural Growth & 5547 & 0.036 & 0.040 \\
\hline lac Agricultural Growth II & 860 & 0.028 & 0.013 \\
hi Agricultural Growth II & 731 & 0.015 & 0.010 \\
pr Agricultural Growth II & 2107 & 0.029 & 0.030 \\
Agricultural Growth II & 3698 & 0.026 & 0.025 \\
\hline lac Non-Agricultural Growth II & 860 & 0.038 & 0.020 \\
hi Non-Agricultural Growth II & 731 & 0.030 & 0.017 \\
pr Non-Agricultural Growth II & 2107 & 0.038 & 0.041 \\
Non-Agricultural Growth II & 3698 & 0.037 & 0.033 \\
\hline lac Agricultural Share & 782 & 0.150 & 0.094 \\
hi Agricultural Share & 659 & 0.038 & 0.028 \\
pr Agricultural Share & 2431 & 0.278 & 0.146 \\
Agricultural Share & 3872 & 0.211 & 0.155 \\
\hline lac Agricultural Share II & 528 & 0.217 & 0.109 \\
hi Agricultural Share II & 287 & 0.058 & 0.022 \\
pr Agricultural Share II & 956 & 0.291 & 0.132 \\
Agricultural Share II & 1771 & 0.231 & 0.141 \\
\hline lac Labor f. share in agriculture & 688 & 0.391 & 0.146 \\
hi Labor f. share in agriculture & 688 & 0.125 & 0.080 \\
pr Labor f share in agriculture & 2279 & 0.670 & 0.202 \\
\hline
\end{tabular}

Note: Lac $=$ Latin American Countries;hi $=$ High income countries; pr=Poor Non LAC countries.

Data Sources: WDI 2003 World Bank, Faostat 2003, and author's calculations. 


\section{Appendix B: Granger Causality Test Country List .}

\begin{tabular}{|c|c|c|c|c|c|}
\hline full sample & $\begin{array}{l}\text { reduced } \\
\text { sample }\end{array}$ & full sample & $\begin{array}{l}\text { reduced } \\
\text { sample }\end{array}$ & full sample & $\begin{array}{c}\text { reduced } \\
\text { sample }\end{array}$ \\
\hline 1 Albania & & 44 Germany & & 87 Norway & $*$ \\
\hline 2 Algeria & $*$ & 45 Ghana & $*$ & 88 Pakistan & $*$ \\
\hline 3 Angola & & 46 Greece & & 89 Panama & $*$ \\
\hline 4 Argentina & * & 47 Guatemala & $*$ & 90 Papua New Guinea & $*$ \\
\hline 5 Armenia & & 48 Guinea & & 91 Paraguay & $*$ \\
\hline 6 Australia & $*$ & 49 Guinea-Bissau & & 92 Peru & $*$ \\
\hline 7 Austria & $*$ & 50 Guyana & & 93 Philippines & $*$ \\
\hline 8 Azerbaijan & & 51 Honduras & $*$ & 94 Poland & \\
\hline 9 Bangladesh & $*$ & 52 Hungary & $*$ & 95 Portugal & $*$ \\
\hline 10 Belarus & & 53 India & $*$ & 96 Romania & \\
\hline 11 Belgium & & 54 Indonesia & $*$ & 97 Russian Federation & \\
\hline 12 Benin & * & 55 Iran, Islamic Rep. & $*$ & 98 Rwanda & $*$ \\
\hline 13 Bolivia & $*$ & 56 Italy & $*$ & 99 Senegal & $*$ \\
\hline 14 Bosnia and Herzegovina & & 57 Jamaica & $*$ & 100 Sierra Leone & \\
\hline 15 Brazil & $*$ & 58 Japan & $*$ & 101 Singapore & $*$ \\
\hline 16 Bulgaria & & 59 Jordan & $*$ & 102 Slovak Republic & \\
\hline 17 Burkina Faso & $*$ & 60 Kazakhstan & & 103 Slovenia & $*$ \\
\hline 18 Burundi & $*$ & 61 Kenya & $*$ & 104 South Africa & $*$ \\
\hline 19 Cambodia & & 62 Korea, Rep. & $*$ & 105 Spain & \\
\hline 20 Cameroon & $*$ & 63 Kyrgyz Republic & & 106 Sri Lanka & $*$ \\
\hline 21 Canada & $*$ & 64 Lao PDR & & 107 Sweden & \\
\hline 22 Central African Republic & & 65 Latvia & $*$ & 108 Syrian Arab Republic & \\
\hline 23 Chad & & 66 Lebanon & & 109 Tajikistan & \\
\hline 24 Chile & $*$ & 67 Lesotho & $*$ & 110 Tanzania & $*$ \\
\hline 25 China & $*$ & 68 Macedonia, FYR & $*$ & 111 Thailand & $*$ \\
\hline 26 Colombia & $*$ & 69 Madagascar & $*$ & 112 Togo & $*$ \\
\hline 27 Comoros & & 70 Malawi & $*$ & 113 Trinidad and Tobago & $*$ \\
\hline 28 Congo, Dem. Rep. & & 71 Malaysia & $*$ & 114 Tunisia & $*$ \\
\hline 29 Congo, Rep. & $*$ & 72 Mali & & 115 Turkey & $*$ \\
\hline 30 Costa Rica & & 73 Mauritania & & 116 Turkmenistan & \\
\hline 31 Cote d'Ivoire & $*$ & 74 Mauritius & $*$ & 117 Uganda & \\
\hline 32 Croatia & & 75 Mexico & $*$ & 118 Ukraine & \\
\hline 33 Czech Republic & & 76 Moldova & & 119 United Kingdom & \\
\hline 34 Denmark & $*$ & 77 Mongolia & & 120 United States & $*$ \\
\hline 35 Dominican Republic & $*$ & 78 Morocco & $*$ & 121 Uruguay & $*$ \\
\hline 36 Ecuador & $*$ & 79 Mozambique & & 122 Uzbekistan & \\
\hline 37 Egypt, Arab Rep. & * & 80 Namibia & & 123 Venezuela, RB & $*$ \\
\hline 38 El Salvador & $*$ & 81 Nepal & $*$ & 124 Vietnam & \\
\hline 39 Eritrea & & 82 Netherlands & & 125 West Bank and Gaza & \\
\hline 40 Estonia & & 83 New Zealand & $*$ & 126 Yemen, Rep. & \\
\hline 41 Ethiopia & $*$ & 84 Nicaragua & $*$ & 127 Zambia & $*$ \\
\hline 42 Finland & $*$ & 85 Niger & $*$ & 128 Zimbabwe & $*$ \\
\hline 43 France & $*$ & 86 Nigeria & $*$ & & \\
\hline
\end{tabular}




\section{Appendix C: Data Sources and Definitions.}

\section{From the World Development Indicators 2003:}

Series: Agriculture, value added

Definition

Agriculture corresponds to ISIC divisions 1-5 and includes forestry, hunting, and fishing, as well as cultivation of crops and livestock production. Value added is the net output of a sector after adding up all outputs and subtracting intermediate inputs. It is calculated without making deductions for depreciation of fabricated assets or depletion and degradation of natural resources. The origin of value added is determined by the International Standard Industrial Classification (ISIC), revision 3. Data are in constant 1995 U.S. dollars.

Source:

World Bank national accounts data, and OECD National Accounts data files.

Series: Industry, value added

Definition

Industry corresponds to ISIC divisions 10-45 and includes manufacturing (ISIC divisions 15-37). It comprises value added in mining, manufacturing (also reported as a separate subgroup), construction, electricity, water, and gas. Value added is the net output of a sector after adding up all outputs and subtracting intermediate inputs. It is calculated without making deductions for depreciation of fabricated assets or depletion and degradation of natural resources. The origin of value added is determined by the International Standard Industrial Classification (ISIC), revision 3. Data are in constant 1995 U.S. dollars. Source:

World Bank national accounts data, and OECD National Accounts data files.

Series: Food, beverages and tobacco ( $\%$ of value added in manufacturing)

Definition

Value added in manufacturing is the sum of gross output less the value of intermediate inputs used in production for industries classified in ISIC major division 3. Food, beverages, and tobacco comprise ISIC division 31.

Source:

United Nations Industrial Development Organization, International Yearbook of Industrial Statistics.

Series: Manufacturing, value added

Definition

Manufacturing refers to industries belonging to ISIC divisions 15-37. Value added is the net output of a sector after adding up all outputs and subtracting intermediate inputs. It is calculated without making deductions for depreciation of fabricated assets or depletion and degradation of natural resources. The origin of value added is determined by the International Standard Industrial Classification (ISIC), revision 3. Data are expressed constant 1995 U.S. dollars.

Source:

World Bank national accounts data, and OECD National Accounts data files.

Definition

Series: Mining and quarrying, value added

Value added in mining and quarrying is defined as the value of output of the mining and quarrying industries less the value of intermediate consumption (intermediate inputs). Mining and quarrying is a subset of industry (ISIC 10-14). Data are in constant 1995 U.S. dollars.

Source:

World Bank national accounts data, and OECD National Accounts data files. 
Definition

Series: Services, etc., value added

Services correspond to ISIC divisions 50-99. They include value added in wholesale and retail trade (including hotels and restaurants), transport, and government, financial, professional, and personal services such as education, health care, and real estate services. Also included are imputed bank service charges, import duties, and any statistical discrepancies noted by national compilers as well as discrepancies arising from rescaling. Value added is the net output of a sector after adding up all outputs and subtracting intermediate inputs. It is calculated without making deductions for depreciation of fabricated assets or depletion and degradation of natural resources. The industrial origin of value added is determined by the International Standard Industrial Classification (ISIC), revision 3. Data are in current local currency. Source:

World Bank national accounts data, and OECD National Accounts data files.

Definition

Series: Labor force, total

Total labor force comprises people who meet the International Labour Organization definition of the economically active population: all people who supply labor for the production of goods and services during a specified period. It includes both the employed and the unemployed. While national practices vary in the treatment of such groups as the armed forces and seasonal or part-time workers, in general the labor force includes the armed forces, the unemployed, and first-time job-seekers, but excludes homemakers and other unpaid caregivers and workers in the informal sector.

Source:

International Labour Organization, using World Bank population estimates.

Definition

Series: Population, total

Total population is based on the de facto definition of population, which counts all residents regardless of legal status or citizenship--except for refugees not permanently settled in the country of asylum, who are generally considered part of the population of their country of origin.

Source:

World Bank staff estimates from various sources including census reports, the United Nations Statistics Division's Population and Vital Statistics Report, country statistical offices, and Demographic and Health Surveys from national sources and Macro International.

Series: CO2 emissions (kg per 1995 US\$ of GDP)

Definition:

Carbon dioxide emissions are those stemming from the burning of fossil fuels and the manufacture of cement. They include contributions to the carbon dioxide produced during consumption of solid, liquid, and gas fuels and gas flaring.

Source:

Carbon Dioxide Information Analysis Center, Environmental Sciences Division, Oak Ridge National Laboratory, in the U.S. state of Tennessee.

Series: Forest area (sq. km)

Definition:

Forest area is land under natural or planted stands of trees, whether productive or not.

Source:

Food and Agriculture Organization, Production Yearbook and data files.

Series: Freshwater resources per capita (cubic meters)

Definition: 
Freshwater resources refer to total renewable resources, which include internal flows of rivers and groundwater from rainfall in the country, and net river flows from other countries. Freshwater resources per capita are calculated using the World Bank's population estimates.

Source:

World Resources Institute.

Series: Freshwater use ( $\%$ of total water resources)

Definition:

Freshwater use refers to total freshwater withdrawals for domestic, industrial, and agricultural use, not counting evaporation losses from storage basins. Total resources refer to total renewable resources, which include internal flows of rivers and groundwater from rainfall in the country, and net river flows from other countries. Withdrawals also include water from desalination plants in countries where they are a significant source, and can exceed 100 percent of total renewable resources where extraction from nonrenewable aquifers or desalination plants is considerable or where there is significant water reuse.

Source:

World Resources Institute.

From Dollar and Kraay (2002):

Quintile Income Shares.

From Faostat 2003 and authors calculations:

Size of the agricultural labor force. 